ENVIRONMENTAL RESTORATION PROGRAM

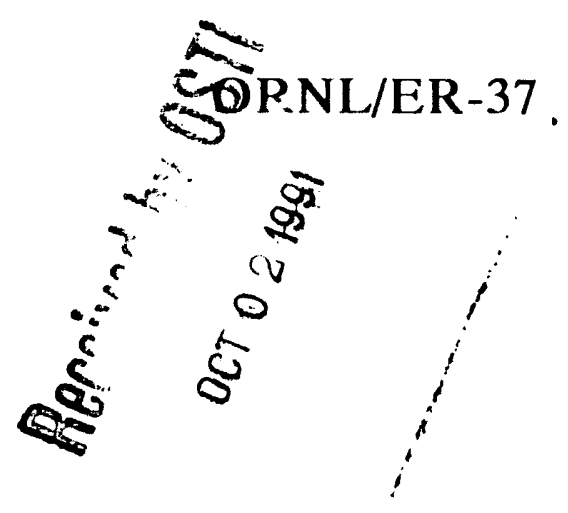

Surface Radiological Investigations of Trench 6 and

Low-Level Waste Line Leak Site 7.4b. at the

Oak Ridge National Laboratory, Oak Ridge, Tennessee

M. S. Uziel

P. F. Tiner

J. K. Williams 
This report has been reproduced directly from the best available copy.

Available to DOE and DOE contractors from the Office of Scientific and Technical Information, P.O. Box 62, Oak Ridge, TN 37831; prices available from 615-576-8401, FTS 626-8401.

Available to the public from the National Technical Information Service, U.S. Department of Commerce, 5285 Port Royal Rd., Springfield, VA 22161. 


\author{
Environmental Restoration Division \\ ORNL Environmental Restoration Program
}

\title{
Surface Radiological Investigations of Trench 6 and Low-Level Waste Line Leak Site 7.4b at the Oak Ridge National Laboratory, Oak Ridge, Tennessee
}

\author{
M. S. Uziel \\ P. F. Tiner \\ J. K. Williams
}

Date Issued-August 1991

Prepared by

Health and Safety Research Division

Prepared for U.S. Department of Energy

Office of Environmental Restoration and Waste Management under budget and reporting code EW 20

OAK RIDGE NATIONAL LABORATORY

Oak Ridge, Tennessee 37831-6285 managed by

MARTIN MARIETTA ENERGY SYSTEMS, INC. for the U.S. DEPARTMENT OF ENERGY under contract DE-AC05-84OR21400) 


\section{Author Affiliations}

M. S. Uziel, P. F. Tiner, and J. K. Williams are members of the Health and Safety Research Division, Oak Ridge National Laboratory, Martin Marietta Energy Systems, Inc. 


\section{CONTENTS}

FIGURES $\ldots \ldots \ldots \ldots \ldots \ldots \ldots \ldots \ldots \ldots \ldots \ldots \ldots \ldots$

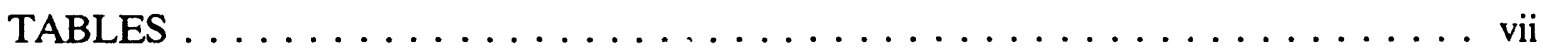

ACKNOWLEDGMENTS $\ldots \ldots \ldots \ldots \ldots \ldots \ldots \ldots \ldots \ldots$ ix

EXECUTIVE SUMMARY $\ldots \ldots \ldots \ldots \ldots \ldots \ldots \ldots \ldots \ldots \ldots \ldots \ldots$

1. INTRODUCTION $\ldots \ldots \ldots \ldots \ldots \ldots \ldots \ldots \ldots \ldots \ldots \ldots \ldots \ldots \ldots$

2. SITE HISTORY $\ldots \ldots \ldots \ldots \ldots \ldots \ldots \ldots \ldots \ldots \ldots \ldots \ldots \ldots \ldots \ldots \ldots$

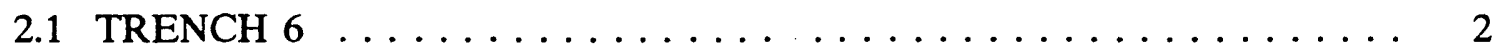

2.2 LLW LINE LEAK SITE $7.4 \mathrm{~b} \ldots \ldots \ldots \ldots \ldots \ldots \ldots \ldots \ldots \ldots \ldots \ldots \ldots$

3. SURVEY METHODS $\ldots \ldots \ldots \ldots \ldots \ldots \ldots \ldots \ldots \ldots \ldots \ldots \ldots \ldots$

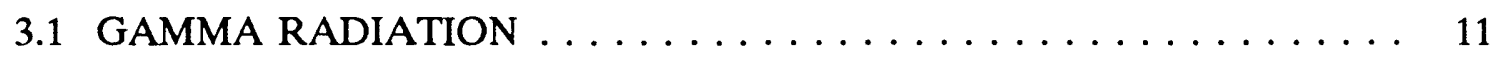

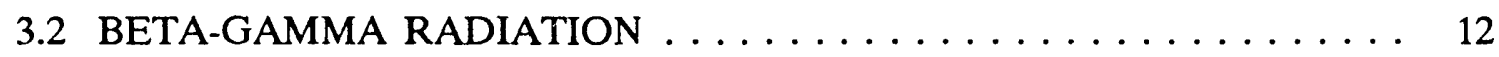

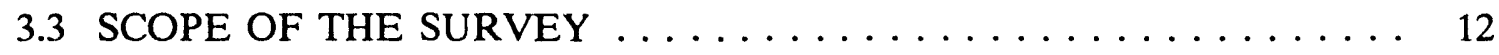

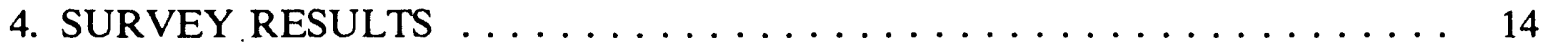

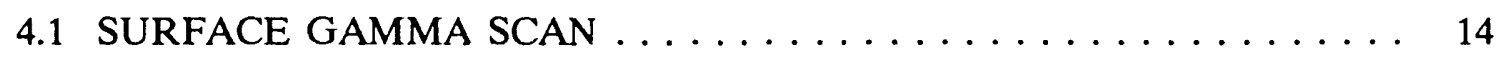

4.2 BETA-GAMMA RADIATION $\ldots \ldots \ldots \ldots \ldots \ldots \ldots \ldots \ldots \ldots \ldots \ldots$

4.3 SOIL SAMPLE ANALYSES $\ldots \ldots \ldots \ldots \ldots \ldots \ldots \ldots \ldots \ldots$

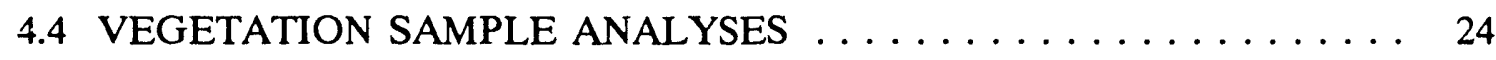

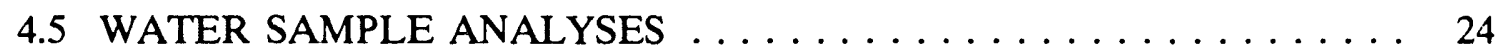

5. SIGNIFICANCE OF FINDINGS $\ldots \ldots \ldots \ldots \ldots \ldots \ldots \ldots \ldots \ldots \ldots$

6. RECOMMENDATIONS FOR CORRECTIVE ACTIONS . . . . . . . 29

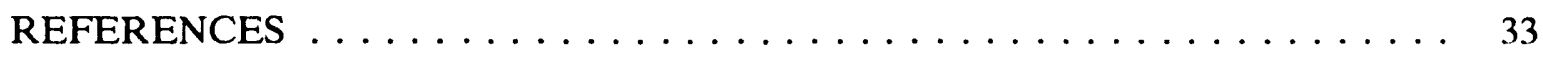




\section{FIGURES}

1 Diagram showing location of Trench 6 in relation to other waste storage areas, the main ORNL complex, and the Clinch River ........................ 3

2 Contour map showing proposed and final location of Trench $6 \ldots \ldots \ldots$

3 View looking east at the north end of Trench 6

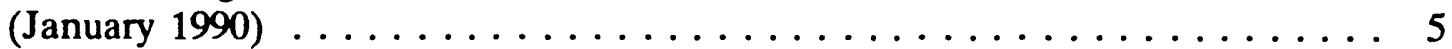

4 View looking west at north end of Trench 6 (January 1990) .......................... 5

5 View looking toward the south end of Trench 6 (January 1990) ............................ 6

6 View of contamination zone sign in the area of former seep (January 1990) . . . . . . . . . . . . . . . . . . . . . . 6

7 Weathered contamination zone sign in area of former seep (January 1990) . . . . . . . . . . . . . . . . . . . . . 7

8 Contour map showing location of LLW Line Leak Site 7.4b (Leak Site No. 1) ....................... 8

9 Diagram showing low-level radioactive waste (LLW) line, Trench 6, and LLW Line Leak Site $7.4 b$ (Leak Site No. 1) . . . . . . 9

10 View looking north at LLW Line Leak Site 7.4b (January 1990) . . . . . . . . . . . . . . . . . . . . . . . 10

11 Diagram showing area covered by the surface radiological survey at Trench 6 and LLW Line Leak Site $7.4 \mathrm{~b} \ldots \ldots \ldots \ldots$

12 Diagram showing results of surface radiological survey and locations of environmental samples at Trench 6 and LLW Line Leak Site $7.4 b$ 
13 View of terra-cotta pipe located north of Trench 6

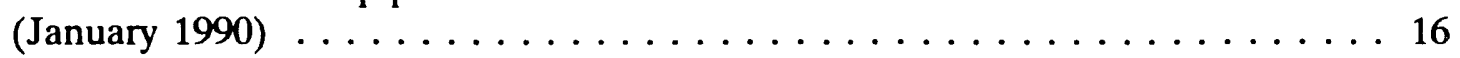

14 View of hot spot just south of LLW Line Leak Site 7.4b

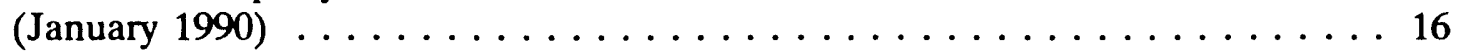

15 View of brush at southwest corner of LLW Line Leak Site 7.4b

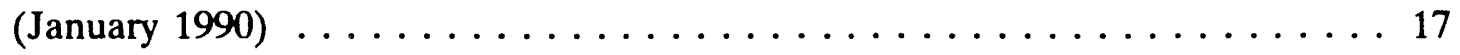

16 View looking north at contaminated trees near southwest end of Trench 6 (January 1990) . . . . . . . . . . . . . . . . . . . 17

17 View from south end of Trench 6 looking southwest at area of contaminated trees (January 1990) $\ldots \ldots \ldots \ldots \ldots \ldots \ldots \ldots \ldots$

18 View looking northeast at ravine that borders south edge of survey site (January 1990) $\ldots \ldots \ldots \ldots \ldots \ldots \ldots \ldots \ldots \ldots \ldots$

19 View showing abandoned pump located in the area of former ser?

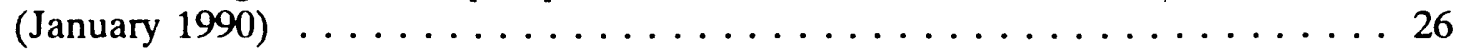

20 View looking north at LLW Line Leak Site 7.4b

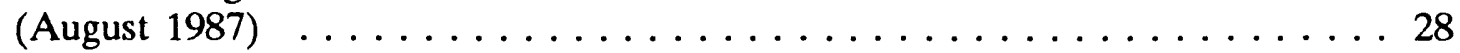




\section{TABLES}

1 Beta-gamma radiation levels measured on tree trunks

in the vicinity of Trench 6 and LLW Line Leak Site $7.4 \mathrm{~b} \ldots \ldots \ldots$

2 Concentrations of ${ }^{60} \mathrm{Co},{ }^{137} \mathrm{Cs}$, gross alpha activity, gross beta activity, and total $\mathrm{Sr}$ in soil samples collected

in the vicinity of Trench 6 and LLW Line Leak Site 7.4b . . . . . . . . 22

3 Concentrations of ${ }^{60} \mathrm{Co},{ }^{137} \mathrm{Cs}$, and gross beta in vegetation samples collected in the vicinity of Trench 6 and LLW Line

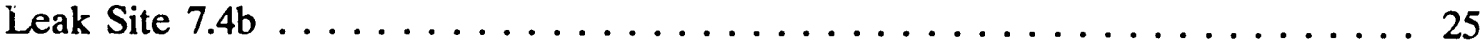




\section{ACKNOWLEDGMENTS}

This project was sponsored by the U.S. Department of Energy's Office of Environmental Restoration and Waste Management in support of the Oak Ridge National Laboratory (ORNL) Environmental Restoration Program (ERP). The authors wish to acknowledge the support of T. W. Burwinkle, H. R. Gaddis, and L. Holder, Jr., of the Office of Waste Management and Remedial Actions, and members of their staffs. P. F. Tiner served as field survey supervisor. The survey team consisted of A. D. Arms (student), V. E. Avery [Summer Teachers as Resources (STAR) program], V. J. Brumback (subcontract staff), D. D. Goff (student), D. C. Landguth, R. A. Mathis, V. P. Patania, and R. J. Watson (subcontract staff). 


\section{EXECUTIVE SUMMARY}

A surface radiological investigation of Trench 6 and low-level radioactive waste (LLW) Line Leak Site 7.4b was conducted in July and August 1989 and January 1990 by the Measurement Applications and Development Group, Oak Ridge National Laboratory. The purposes of this survey were (1) to determine the presence, nature, and extent of surface radiological contamination and (2) to recommend interim corrective action to limit human exposures to radioactivity and minimize the potential for contaminant dispersion.

Highest surface gamma levels encountered during the survey $(39 \mathrm{mR} / \mathrm{h})$ were found just south of the asphalt covering LLW Line Leak Site 7.4b. Elevated surface gamma levels (measuring 28 to $560 \mu \mathrm{R} / \mathrm{h}$ ) extended from this area to a width of $100 \mathrm{ft}$, westward $250 \mathrm{ft}$, and beyond the survey boundary.

Beta-gamma levels up to $17 \mathrm{mrad} / \mathrm{h}$ measured on contact with the trunks of trees growing in the area southwest of Trench 6 suggest that tree roots are reaching contamination deep within the ground. Since no gamma activity is associated with the trees or their leaves, the elevated beta levels are probably due to the uptake of residual ${ }^{90} \mathrm{Sr}$ originating from the documented seepage at the Trench 6/Leak Site $7.4 \mathrm{~b}$ area. Beta activity present in the leaf litter and surface soil indicate that decaying leaves are depositing measurable contaminants on the ground surface.

Recommendations for corrective actions are included. 


\section{INTRODUCTION}

A surface radiological investigation of Trench 6 and low-level radioactive waste (LLW) Line Leak Site 7.4b was conducted in July and August 1989 and January 1990. This survey was performed by the Measurement Applications and Development Group of the Health and Safety Research Division, Oak Ridge National Laboratory (ORNL), at the request of ORNL Environmental Restoration Program (ERP) personnel. The purposes of this survey were (1) to determine the presence, nature, and extent of surface radiological contamination and (2) to recommend interim corrective action to limit human exposures to radioactivity and minimize the potential for contaminant dispersion.

Trench 6 and LLW Line Leak Site 7.4b have been assigned to Waste Area Group (WAG) 7 and to Solid Waste Management Units (SWMUs) 7.8 and 7.4b, respectively, by ORNL ERP staff. 


\section{SITE HISTORY}

\subsection{TRENCH 6 (7806)}

Trench 6 is one of seven ORNL seepage pits and trenches that were used to dispose of approximately 160 million liters (42 million gallons) of radioactive liquid wastes between 1951 and 1966. Trench 6 was constructed in 1961 on a ridge top just south of SWSA 4 at ORNL grid coordinates (measured in feet) N18,680 and E27,980 (Fig. 1). The actual choice of the site of Trench 6 was based on construction cost estimates rather than geologic advice or preconstruction coring and water table monitoring (Fig. 2). ${ }^{1}$

Trench 6 was built with an earthen cover that served to decrease the radiation field around the trench, to safeguard personnel from accidental falls when working in the vicinity, to prevent wild birds from landing and later transporting radioactivity away from the trench, and to prevent natural precipitation from entering the trench. Trench 6 was almost U-shaped and was approximately $150 \mathrm{~m}(500 \mathrm{ft})$ long and $4 \mathrm{~m}(14 \mathrm{ft})$ deep. The sides sloped steeply from a width of $3 \mathrm{~m}(10 \mathrm{ft})$ at the top to a narrower $1.2-\mathrm{m}(4-\mathrm{ft})$ bottom. The trench was filled to a depth of $3 \mathrm{~m}(10 \mathrm{ft})$ with crushed limestone, which in turn was covered with two thicknesses of polyethylene film followed by $1.2 \mathrm{~m}(4 \mathrm{ft})$ of compacted earth fill. The low-level liquid waste line was extended to Trench 6 and wastes were released into the layer of crushed limestone. ${ }^{1}$

The trench was pretreated with $9000 \mathrm{~kg}(20,000 \mathrm{lb})$ of copper sulfate dissolved in $520,000 \mathrm{~L}(140,000 \mathrm{gal})$ of water in an attempt to prevent ${ }^{106} \mathrm{Ru}$ seepage, a common problem at that time. On September 7, 1961, the pit received its first waste discharge. On October 5, sampling revealed the presence of ${ }^{90} \mathrm{Sr}$ and ${ }^{137} \mathrm{Cs}$ in a seep located about $90 \mathrm{~m}$ $(100 \mathrm{yd})$ south of the trench. The liquid was seeping at a rate of $9 \times 10^{-6} \mathrm{~m}^{3} / \mathrm{s}(0.15 \mathrm{gal} / \mathrm{min})$ and the radiation field measured $20 \mathrm{mR} / \mathrm{h}$ in the contaminated area. The trench was taken out of service on October 10,1961, and a new trench was constructed within a year. Trench 6 received only about $490,000 \mathrm{~L}$ (130,000 gal) containing $145 \mathrm{Ci}{ }^{90} \mathrm{Sr}, 665 \mathrm{Ci}{ }^{137} \mathrm{Cs}, 500 \mathrm{Ci}$

${ }^{106} \mathrm{Ru}$, and $24 \mathrm{Ci}{ }^{60} \mathrm{Co}$. It was covered with asphalt in $1981 .{ }^{1}$

Currently, the asphalt-covered area at Trench 6 is surrounded by a 3 -ft barbed wire fence (Figs. 3-5). The area of the former seep is marked by two old weather-beaten contamination zone signs (Figs. 6 and 7) and an abandoned pump. The former-seep area is not roped off.

\subsection{LLW LINE LEAK SITE 7.4b}

LLW Line Leak Site 7.4b is one of a number of leak sites identified along the LLW line that from 1952 to 1975 transferred liquid wastes to the pits and trenches and to the first hydrofracture site. Leak Site 7.4b, also known as Leak Site No. 1 and as the North Leak Site, is located approximately $46 \mathrm{~m}$ (150 ft) south of Trench 6 at ORNL coordinates N18,363 and E27,976 (Figs. 8 and 9). The leak at a connector between adjacent sections 

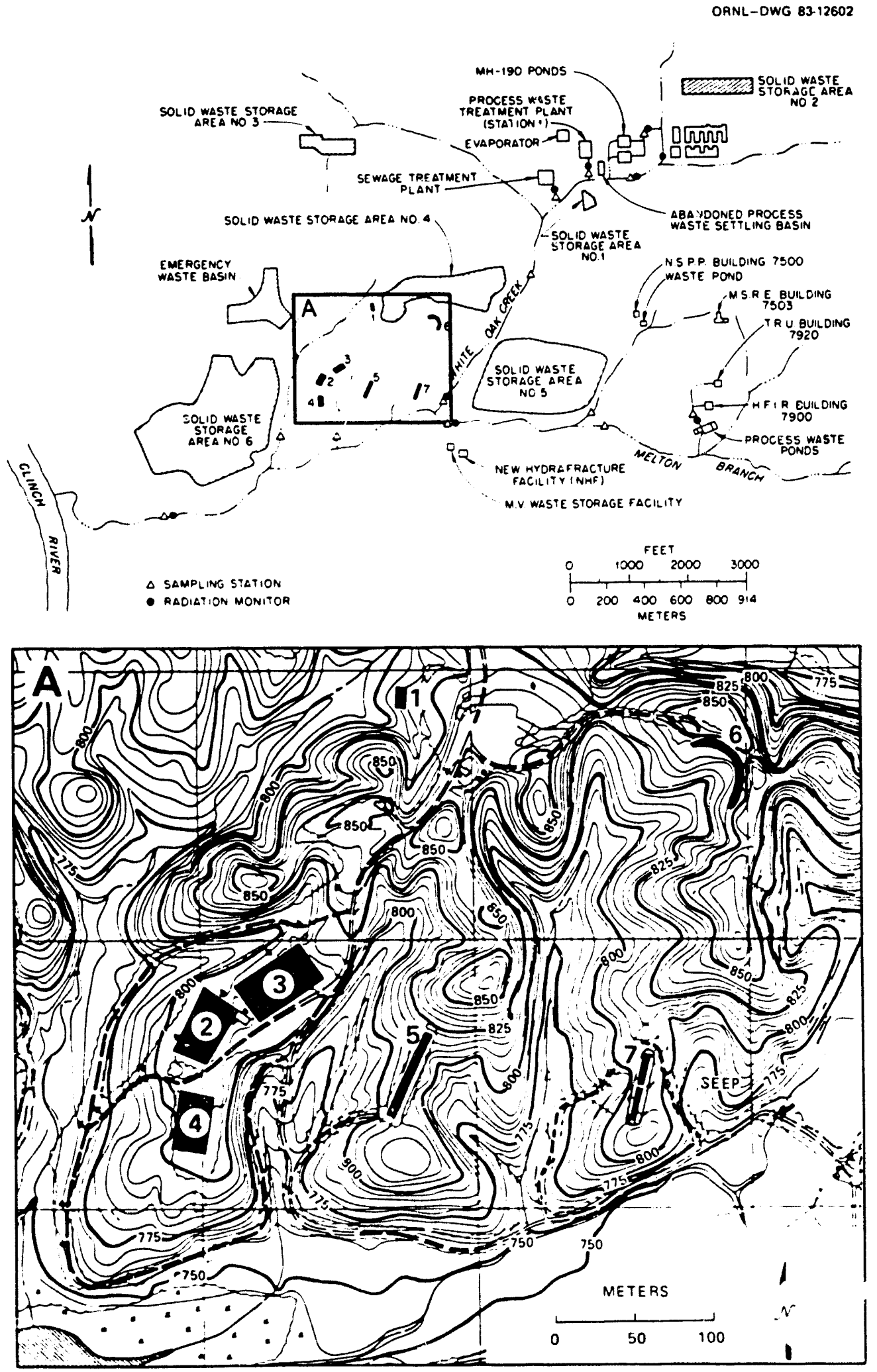

Fig. 1. Diagram showing location of Trench 6 in rclation to other waste storage arcas, the main ORNL complex, and the Clinch River. 


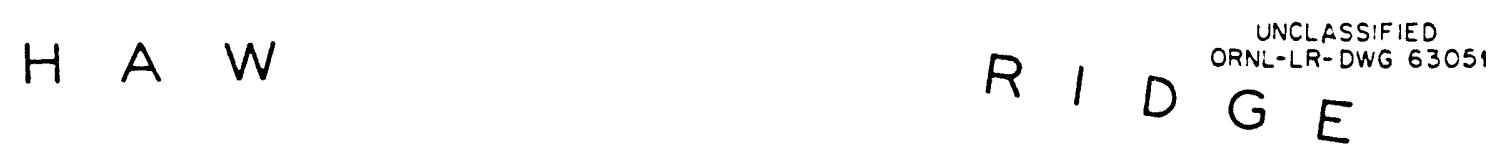

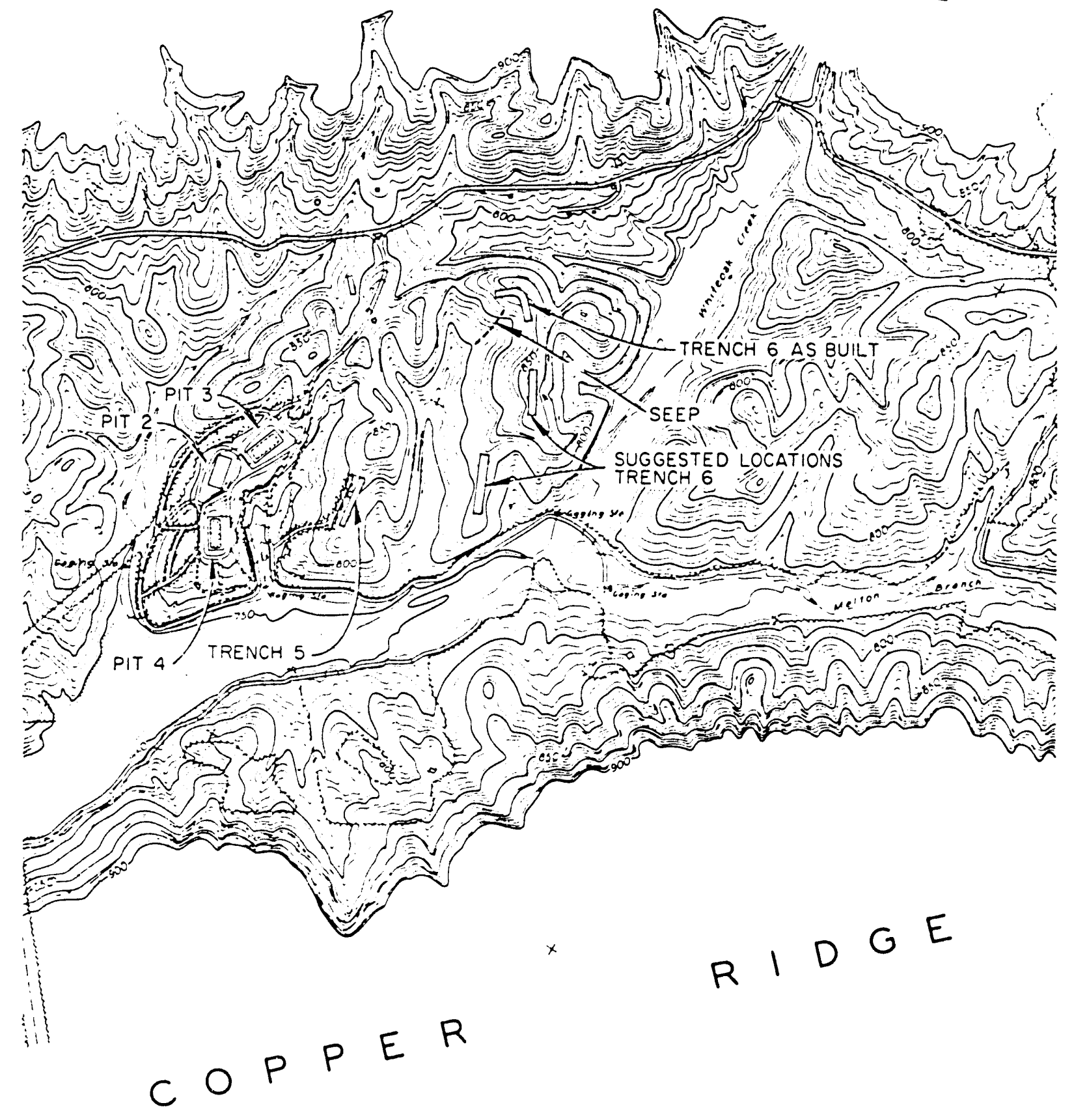

Fig. 2. Contour map showing proposed and final location of Trench 6. 


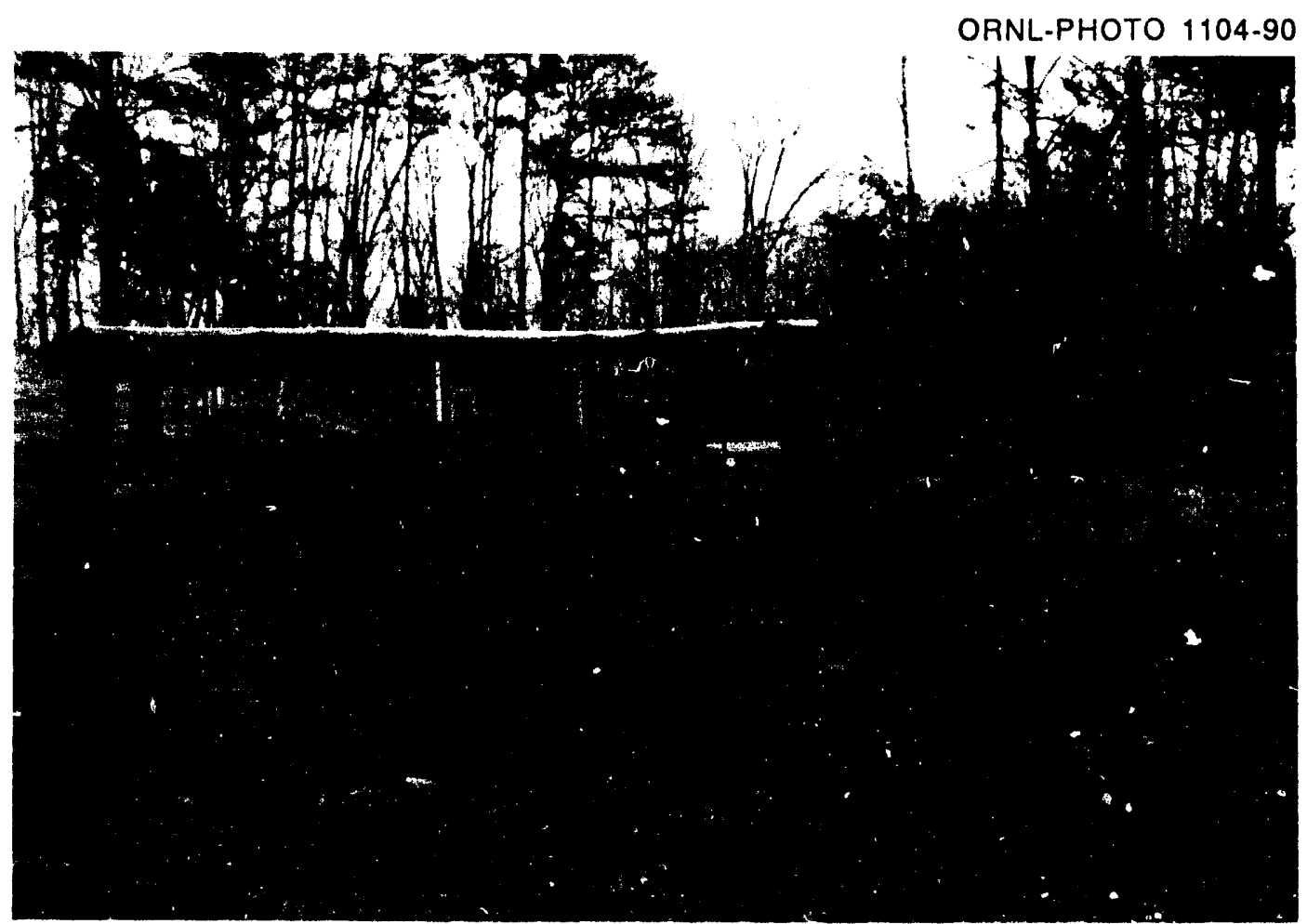

Fig. 3. View looking east at the north end of Trench 6 (January 1990).

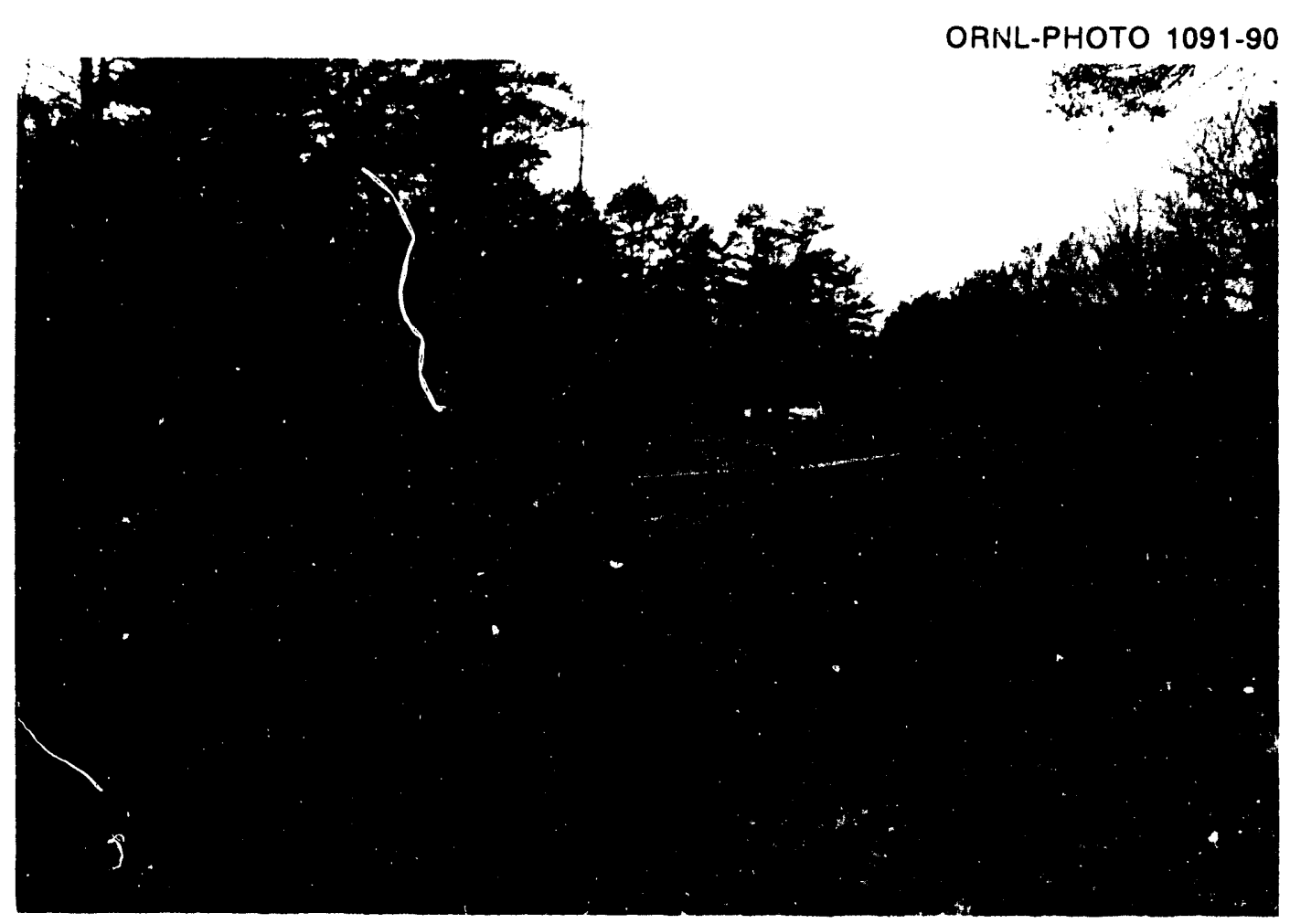

Fig. 4. View looking west at north end of Trench 6 (January 1990). 


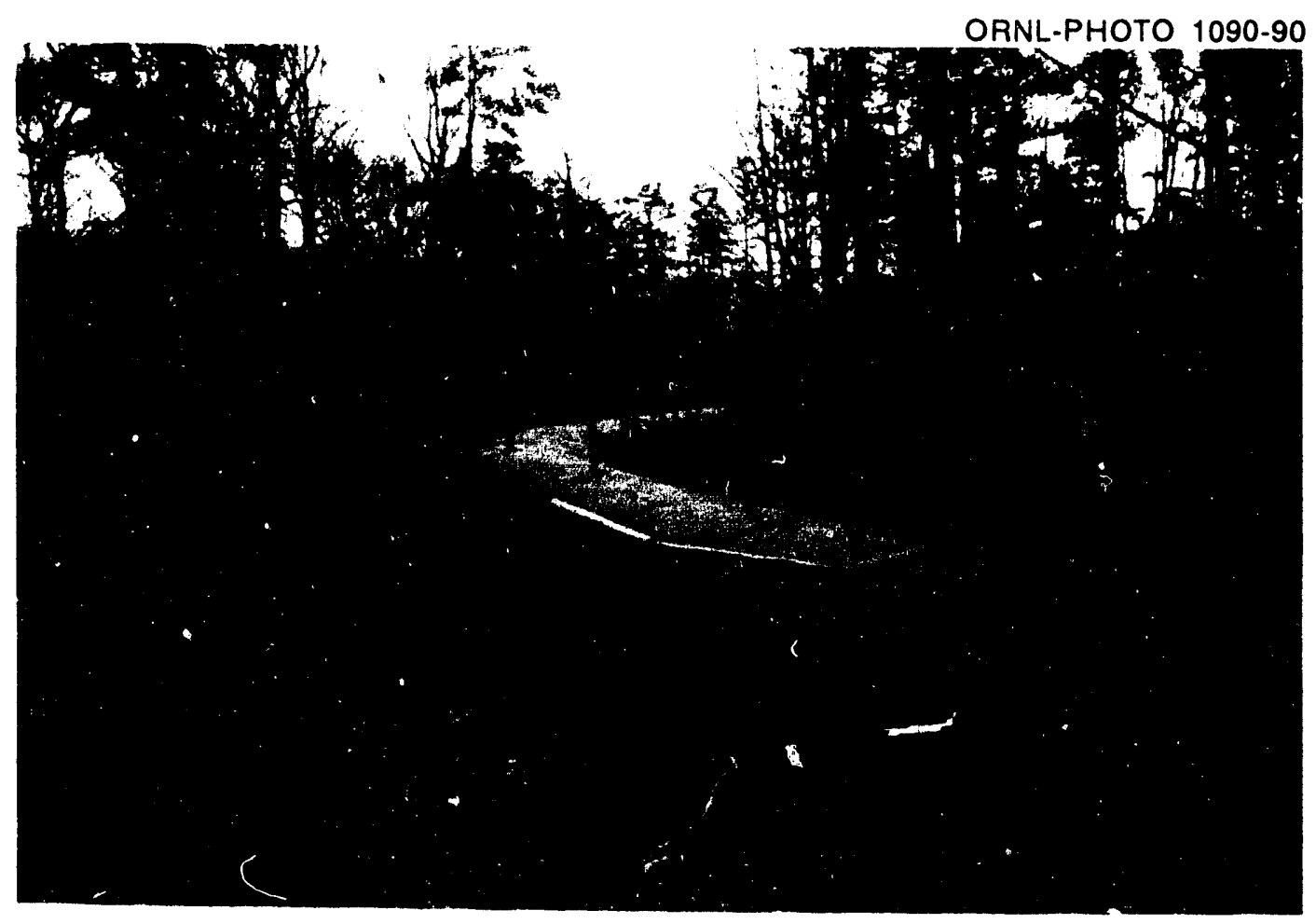

Fig. 5. View looking toward the south end of Trench 6 (January 1990).

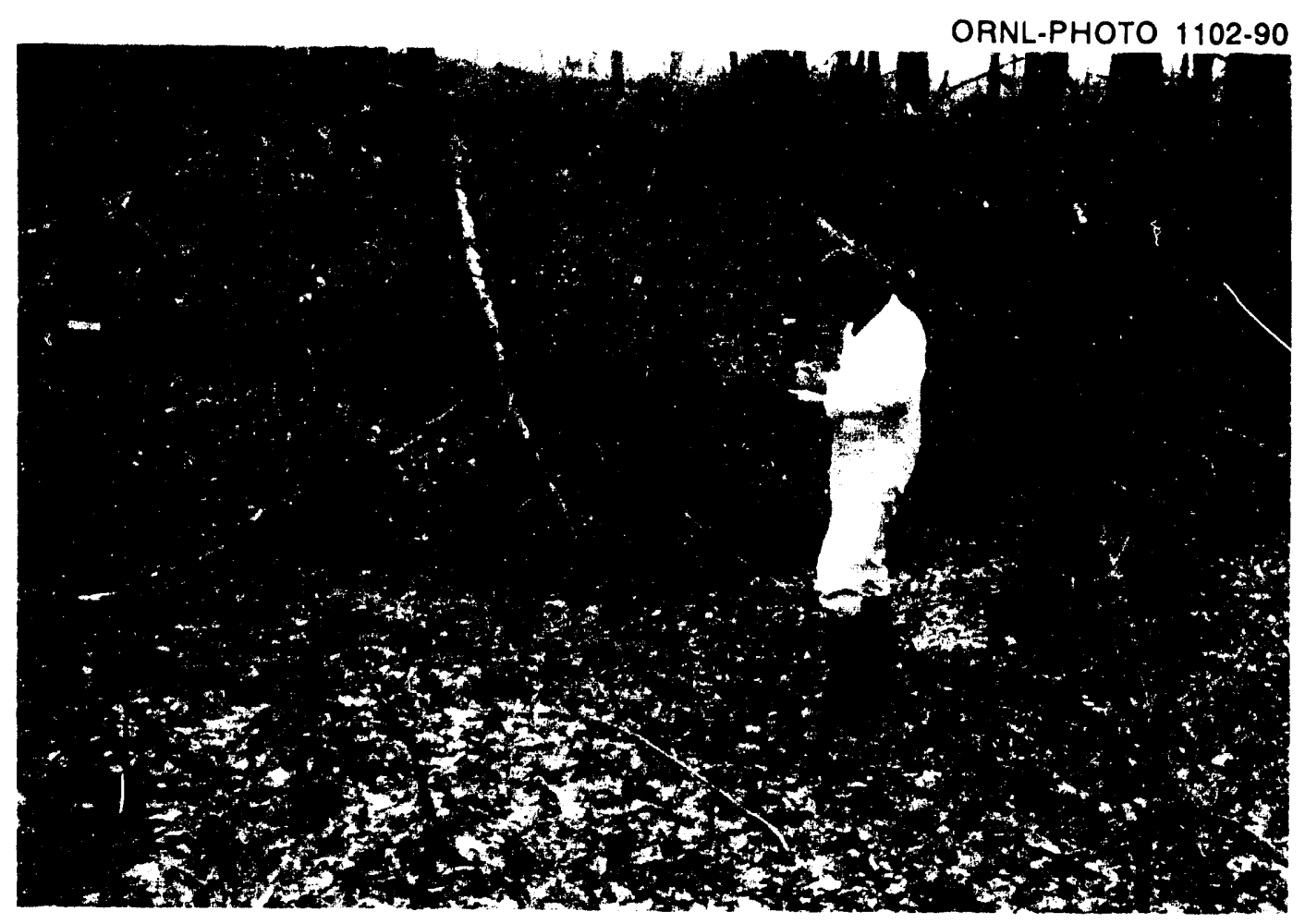

Fig. 6. View of contamination zone sign in the area of former seep (January 1990). 


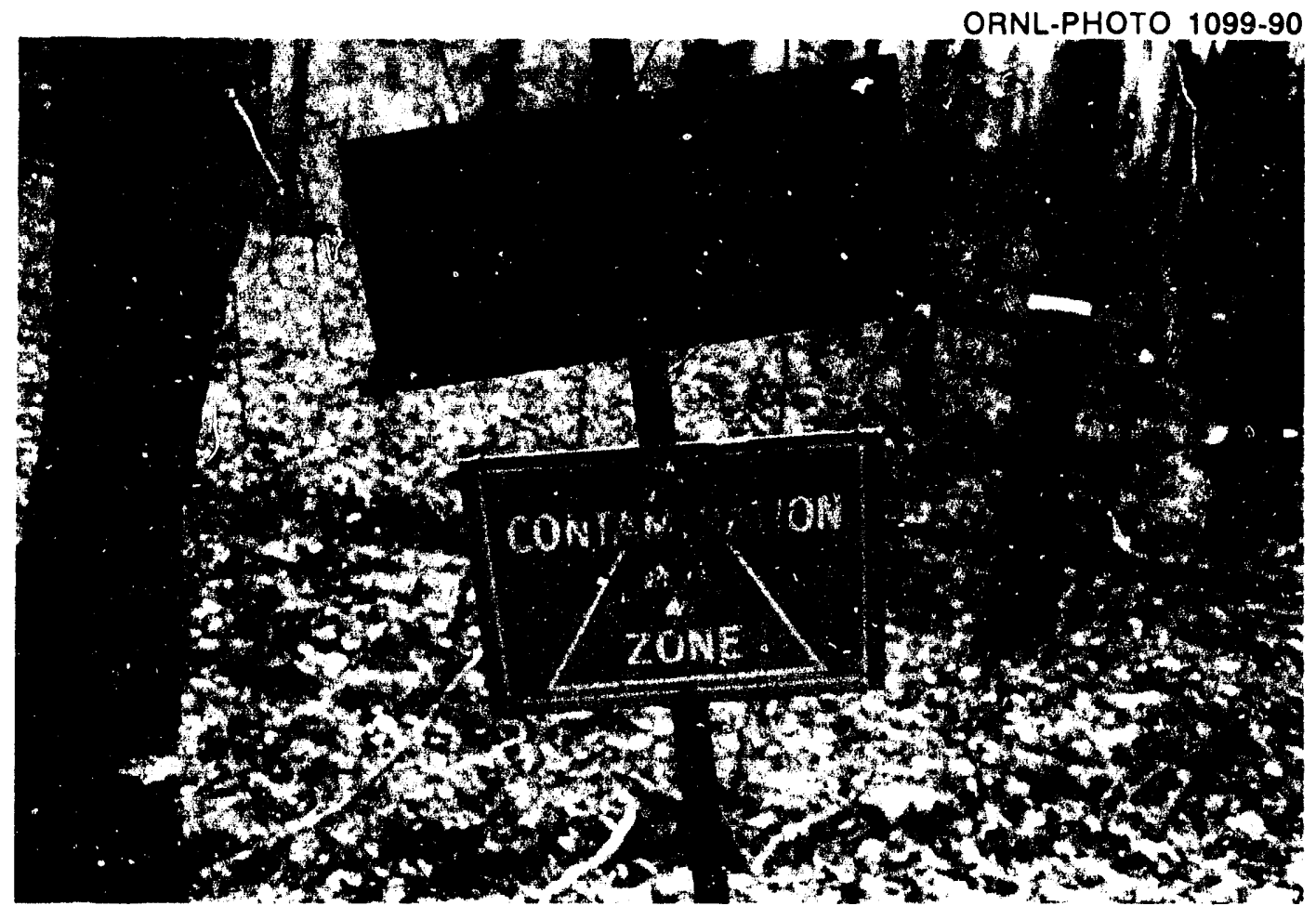

Fig. 7. Weathered contamination zone sign in area of former seep (January 1990). 


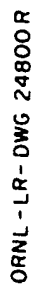

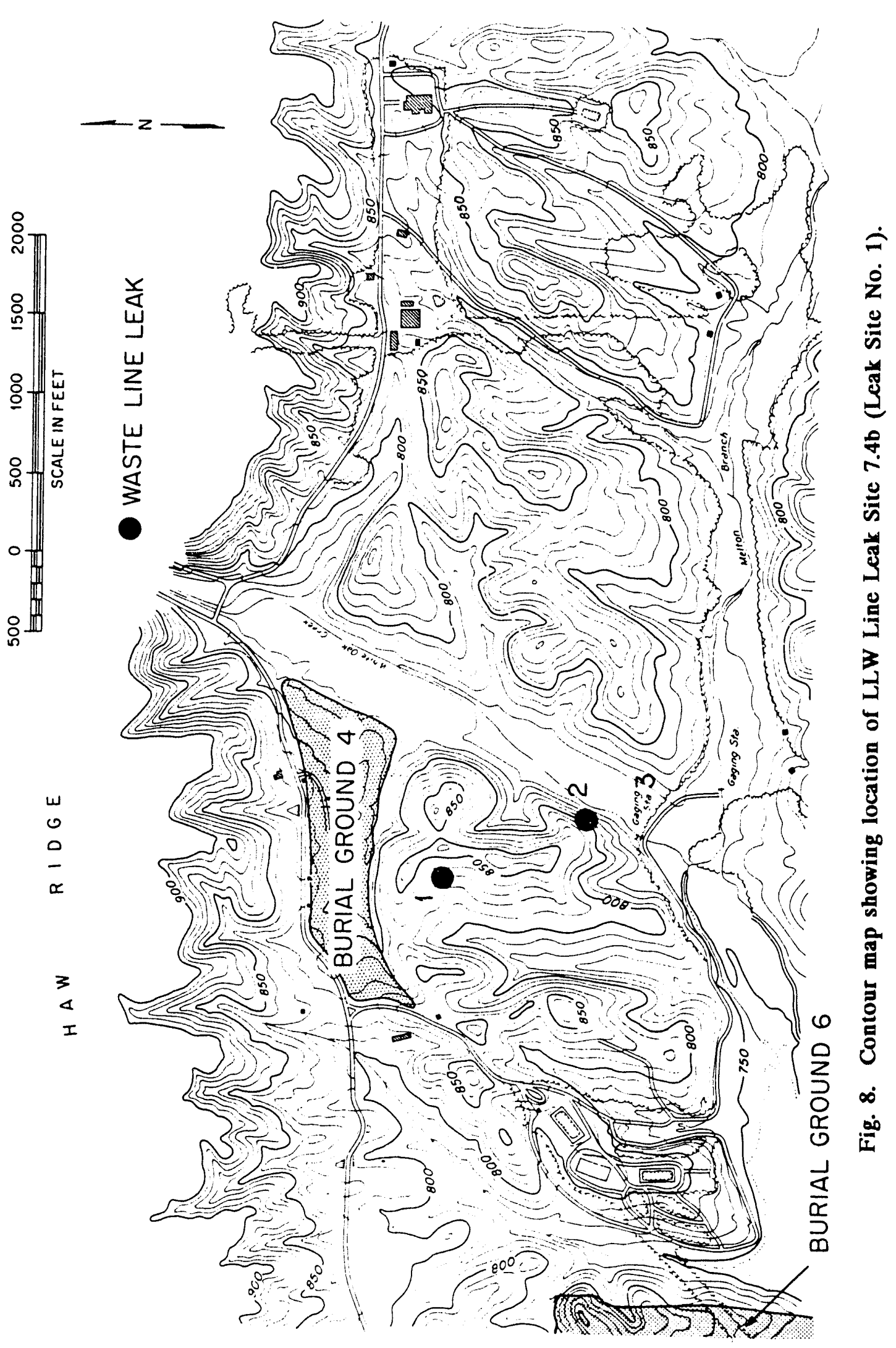




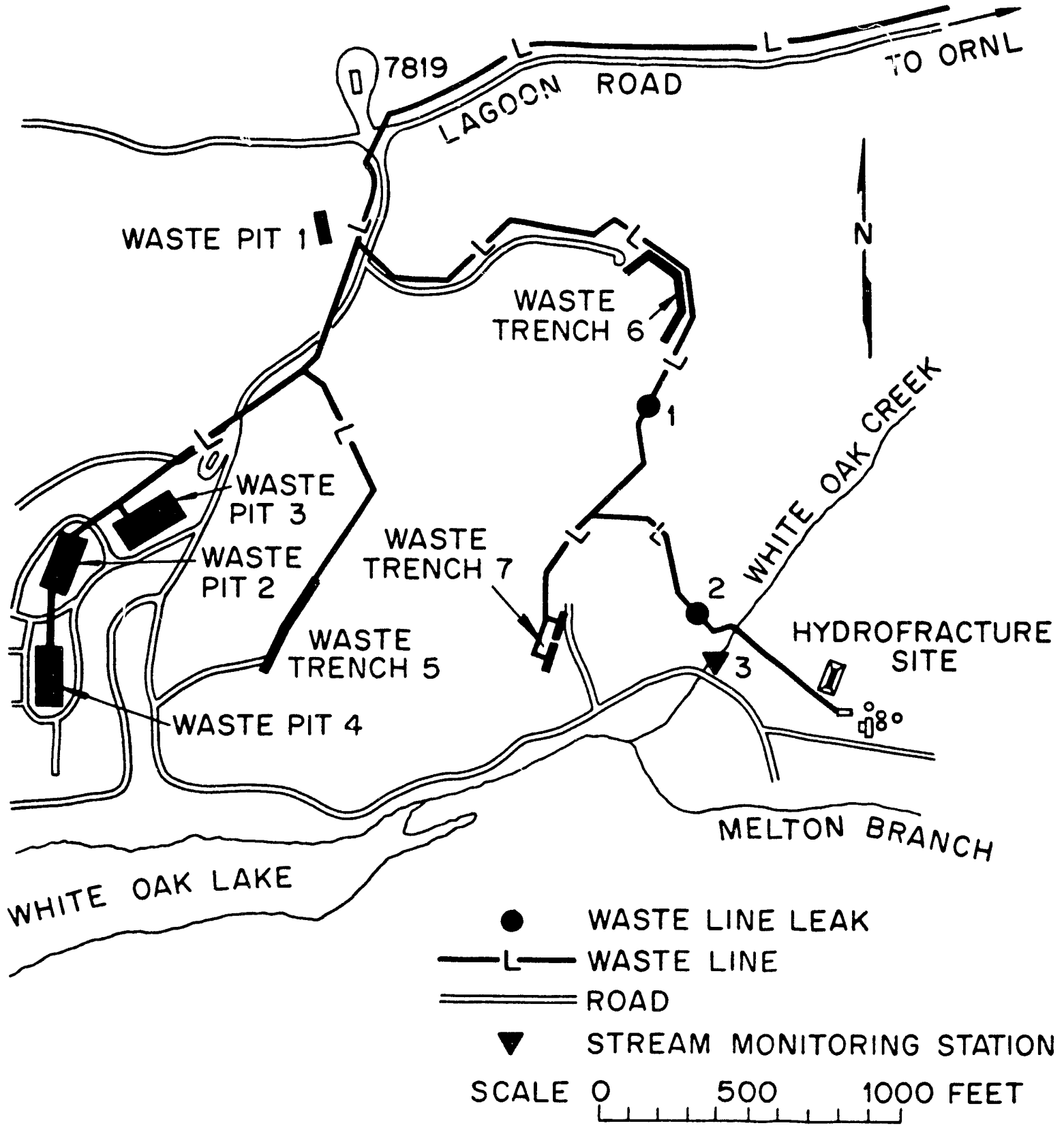

Fig. 9. Diagram showing low-level radioactive waste (LLW) line, Trench 6, and LLW Line Leak Site 7.4b (Leak Site No. 1). 
of pipe was reported in July 1973 but apparently had occurred at an earlier date. ${ }^{1}$ Wastes carried in the system were evaporator-concentrated laboratory LLW routinely containing ${ }^{90} \mathrm{Sr},{ }^{137} \mathrm{Cs},{ }^{106} \mathrm{Ru},{ }^{60} \mathrm{Co}$, various rare earths, and some plutonium, uranium, and transuranic isotopes.

Nine soil samples taken at the site in 1973 showed beta-gamma activity ranging from $<0.01$ to $50 \mu \mathrm{Ci} / \mathrm{g}$ and gross alpha levels up to $1 \mathrm{nCi} / \mathrm{g}$. The beta-gamma activity was due primarily to ${ }^{137} \mathrm{Cs}$ and ${ }^{90} \mathrm{Sr}$. The main alpha emitter was ${ }^{244} \mathrm{Cm}$, with minor amounts of ${ }^{241} \mathrm{Am},{ }^{238} \mathrm{Pu}$, and ${ }^{239} \mathrm{Pu} .{ }^{1}$ In 1979 , beta-gamma measurements at $1 \mathrm{~m}(3.3 \mathrm{ft})$ above the ground surface ranged from $240 \mathrm{mrad} / \mathrm{h}$ to $1 \mathrm{rad} / \mathrm{h},{ }^{2}$ with an area about 6 by $6 \mathrm{~m}$ (20 by $20 \mathrm{ft}$ ) containing most of the radiation. ${ }^{1}$

Efforts to restrict the flow of surface water through the site were begun in 1983 . The pipeline was cut, short sections were removed, and the open ends were sealed. Contaminated soil and vegetation were removed before a subsurface bentonite clay cap and a surface asphaltic concrete cap were installed. The covered area was fenced with barbed wire and the remaining disturbed area seeded with grass. ${ }^{1}$

Currently, the asphalt cap is surrounded by a barbed wire fence and limestone riprap (Fig. 10).

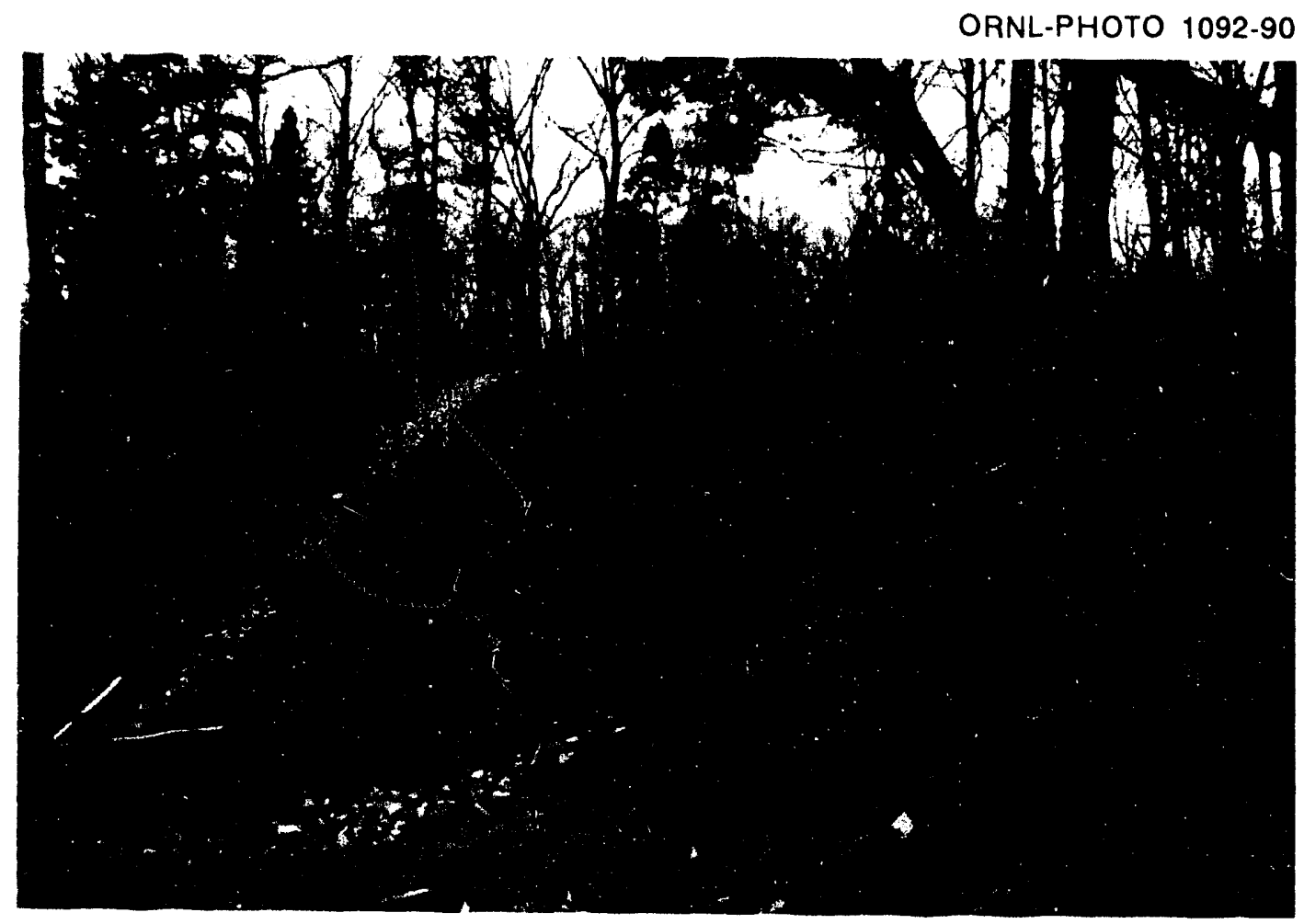

Fig. 10. View looking north at LLW Line Leak Site 7.4b (January 1990). Flags at bottom center mark sample iocations $B 1$ and V3. 


\section{SURVEY METHODS}

A comprehensive description of the methods and instrumentation used in this survey is presented in Procedures Manual for the ORNL Radiological Sunvey Activities (RASA) Program, Oak Ridge National Laboratory, ORNL/TM-8600 (April 1987). ${ }^{3}$ All direct measurement results presented in this report are gross readings; background radiation levels have not been subtracted. Similarly, background concentrations have not been subtracted from radionuclide concentrations measured in environmental samples. Counting errors near to or greater than measured radionuclide concentrations in environmental samples indicate the radionuclide is probably not present.

The area was not divided into grid blocks. All references to grid location are approximate.

\subsection{GAMMA RADIATION}

Gamma radiation was measured with a sodium iodide $(\mathrm{NaI})$ scintillation probe connected to a Victoreen Model 490 Thyac III ratemeter. Because NaI gamma scintillators are energy dependent, measurements of gamma radiation levels made with these instruments must be normalized to pressurized ionization chamber (PIC) measurements to estimate gamma exposure rates. The function developed for these conversions is:

$$
y=x \times \mathrm{CF}
$$

where

$$
\begin{aligned}
y= & \text { the exposure rate in } \mu \mathrm{R} / \mathrm{h}, \\
x= & \text { the scintillometer measurements in thousand counts per minute }(\mathrm{kcpm}), \\
\mathrm{CF}= & \text { the slope of the regression line calculated by plotting a selected number of PIC } \\
& \text { measurements }(\mu \mathrm{R} / \mathrm{h}) \text { vs scintillometer measurements }(\mathrm{kcpm}) \text { at the same locations. }
\end{aligned}
$$

For this site, $\mathrm{CF}=1.4$.

When gamma radiation levels exceedrd the limits of the NaI gamma scintillator $(800,000 \mathrm{cpm})$, measurements made with a closed Geiger-Mueller survey meter (GMSM), Model Q-5218, equipped with a side-window probe $\left(30 \mathrm{mg} / \mathrm{cm}^{2}\right.$ wall thickness), were converted to exposure rates by using the following instrument-specific conversion factor based on ${ }^{226} \mathrm{Ra}$ : 
$3100 \mathrm{cpm}=1 \mathrm{mR} / \mathrm{h} \quad$ or $\quad 3.1 \mathrm{cpm}=1 \mu \mathrm{R} / \mathrm{h}$.

In some cases, measurements made with an open-window GMSM are also noted.*

\subsection{BETA-GAMMA RADIATION}

Beta-gamma energy levels were detected with a portable Bicron miniscaler/ratemeter with an HP-260 or HP-265 Geiger-Mueller pancake detector. The instrument was set in the open configuration to detect beta-gamma and in the closed (shiclded) configuration to detect gamma. After calibration of the detectors to a known strontium source at the ORNL Radiation Calibration Laboratory (RADCAL), beta radiation detection levels in counts per minute were converted to dose rates in millirads per hour using the following relationship:

$$
2800 \mathrm{cpm}=1 \mathrm{mrad} / \mathrm{h} \quad \text { or } \quad(\mathrm{mrad} / \mathrm{h}) / \mathrm{cpm}=0.00036 .
$$

At one contaminated area, radiation was also measured with a paper-shell cutie pie ionization chamber (standard model).

\subsection{SCOPE OF THE SURVEY}

The survey included:

- A surface gamma scan of the area including the asphalt layers on the trench and leak site, the gravel road north of the trench, and wooded regions in the area including the site of a former seep. Area covered in this survey is delineated with a dotted line in Fig. 11. A NaI scintillation probe held approximately $5 \mathrm{~cm}(2 \mathrm{in}$.) above the ground surface was used to detect gamma radiation. When radiation levels exceeded the detection limits of the scintillator, the GMSM or cutic pic ionization chamber was used.

- Measurement of beta-gamma activity on contact with the trunks of numerous contaminated trees.

- Radionuclide analysis of eight soil samples collected from four locations.

- Radionuclide analysis of three vegetation samples collected from three locations.

- Radionuclide analysis of one water sample.

*A closed-window GMSM measures only gamma radiation; an open-window configuration detects both beta and gamma radiation. 
ORNL-DWG $91-8161$

N18,800

N18,600
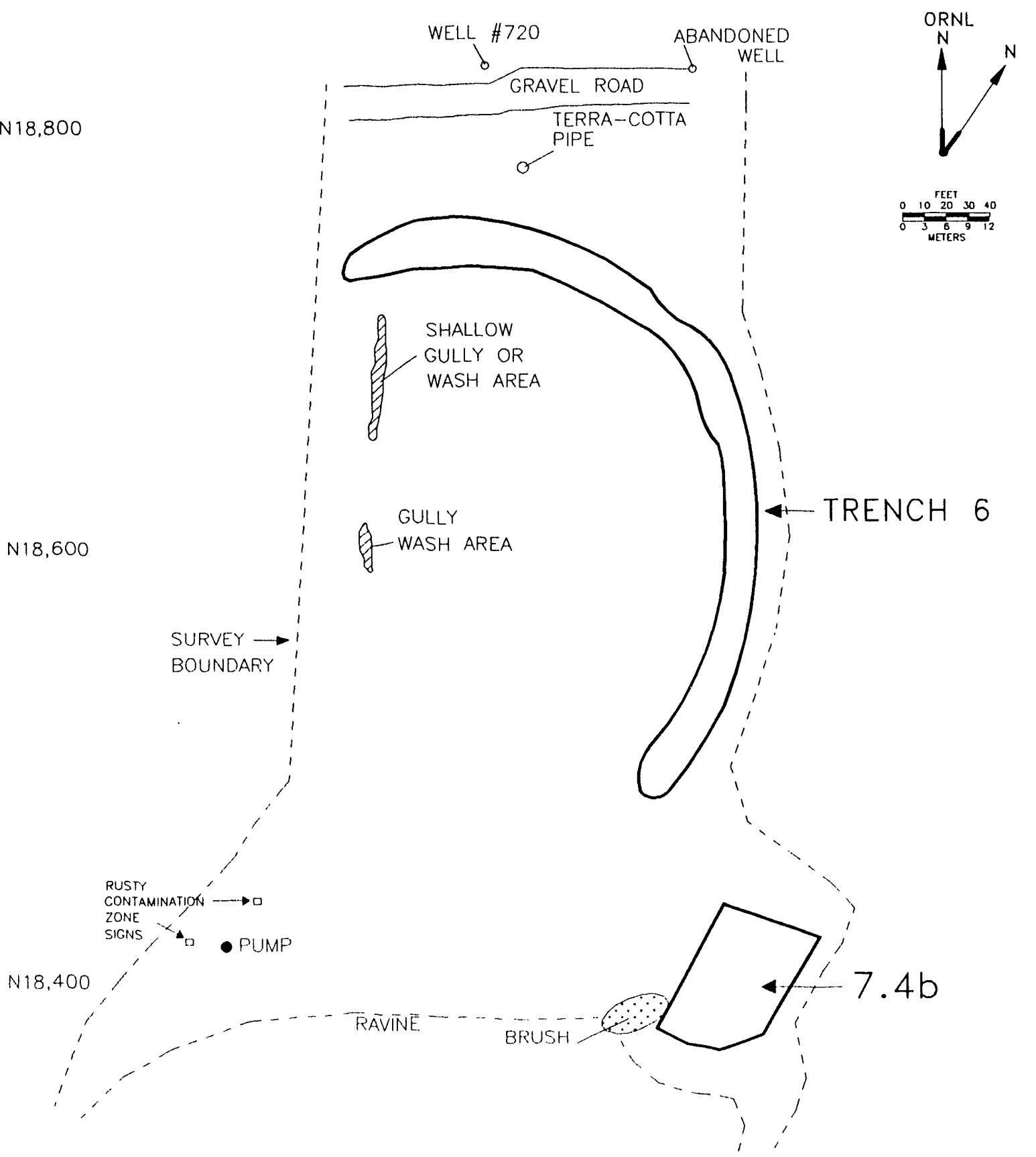

Fig. 11. Diagram showing area covered by the surface radiological survey at Trench 6 and LLW Line Leak Sitc 7.4b. 


\section{SURVEY RESULTS}

\subsection{SURFACE GAMMA SCAN}

Results of the surface gamma scan are shown in Fig. 12. The asphalt covering on Trench 6 showed surface gamma radiation levels ranging from 8 to $17 \mu \mathrm{R} / \mathrm{h}$, with one spot reaching $56 \mu \mathrm{R} / \mathrm{h}$. Gamma levels up to $140 \mu \mathrm{R} / \mathrm{h}$ were recorded on contact with the sides of several pipes (vents) protruding vertically from the asphalt surface.

Surface gamma levels on the gravel road north of Trench 6 ranged from 14 to $21 \mu \mathrm{R} / \mathrm{h}$. Six spots of surface contamination between the gravel road and the north end of Trench 6 ranged from 84 to $840 \mu \mathrm{R} / \mathrm{h}$. In this same area, a terra-cotta pipe about $4 \mathrm{ft}$ in diameter (Figs. 12 and 13) showed gamma radiation levels of $3200 \mu \mathrm{R} / \mathrm{h}$ on contact with the metal cover and $800 \mu \mathrm{R} / \mathrm{h}$ at $1 \mathrm{~m}$ above the edge of the metal cover. Radiation emanating from the pipe ranged from 42 to $560 \mu \mathrm{R} / \mathrm{h}$ over a $13-\mathrm{m}^{2}\left(140-\mathrm{ft}^{2}\right)$ area. A faded radiation hazard sign is affixed to the metal cover but is visible only after one enters the radiation field, walks up to the pipe, and looks down at the cover (Fig. 13).

In a gully just south of the asphalt covering LLW Line Leak Site 7.4b (Fig. 14), surface gamma levels reached $39 \mathrm{mR} / \mathrm{h}$ and beta-gamma levels measured $48 \mathrm{mrad} / \mathrm{h}$. Exposure rates at $1 \mathrm{~m}$ above the ground surface reached $3 \mathrm{mR} / \mathrm{h}$ over a circular area approximately $1.8 \mathrm{~m}$ $(6 \mathrm{ft})$ in diameter. The circle of contamination was part of a much larger contaminated area that extended $6.1 \mathrm{~m}(20 \mathrm{ft})$ south of the leak site, westward for at least $76 \mathrm{~m}(250 \mathrm{ft})$, and then beyond the western survey boundary. The contamination spread to a width of $30 \mathrm{~m}$ $(100 \mathrm{ft})$ at the widest point, and surface gamma levels ranged from 28 to $560 \mu \mathrm{R} / \mathrm{h}$ over most of this larger area (Fig. 12). Contamination did not extend southward beyond a ravine located along the southern survey boundary (Fig. 15).

Surface gamma radiation levels on the asphalt covering Leak Site $7.4 \mathrm{~b}$ ranged from 15 to $30 \mu \mathrm{R} / \mathrm{h}$, except in the southwest corner where radiation emanating from the $39-\mathrm{mR} / \mathrm{h}$ area just south of the asphalt caused surface levels to increase.

Two gullies or surface depressions west of Trench 6 showed surface gamma levels of 28 to $150 \mu \mathrm{R} / \mathrm{h}$ and 28 to $210 \mu \mathrm{R} / \mathrm{h}$. The gullies carry runoff water in wet weather.

\subsection{BETA-GAMMA RADIATION}

More than 50 contaminated trees (Figs. 16 and 17) were found along a line extending from the south end of Trench 6 southwest into the area with elevated surface gamma levels and beyond the western perimeter of the survey area. The area containing contaminated trees is delineated with a dotted line in Fig. 12. Beta-gamma levels measured on contact with the tree trunks ranged from 0.21 to $17 \mathrm{mrad} / \mathrm{h}$. Dead leaves lying on the ground beneath the trees measured $1.6 \mathrm{mrad} / \mathrm{h}$; the soil beneath the leaves measured $0.9 \mathrm{mrad} / \mathrm{h}$ after the leaves were removed. Gamma activity was not associated with the leaf litter or the 
ORNL-DWG 91-8162

N18,800

$N 18,600$
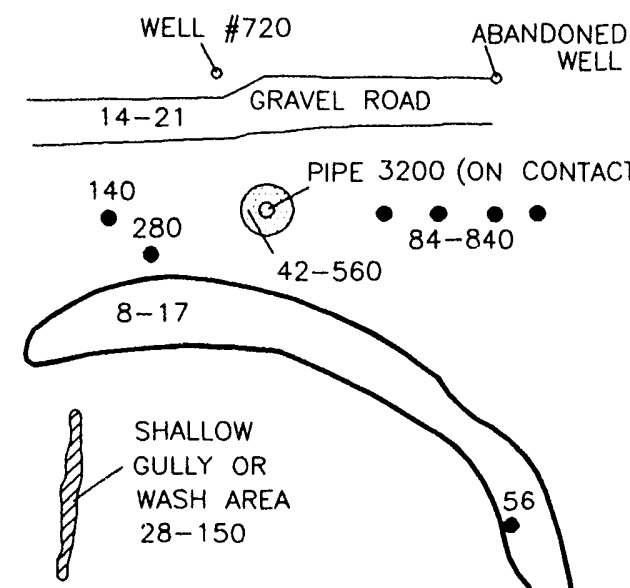

PIPE 3200 (ON CONTACT)

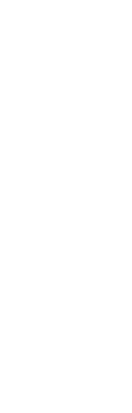
G. WASH AREA
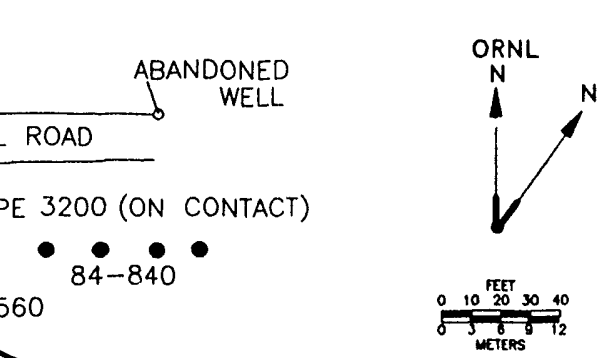

- contaminated stot

$\square$ CONTAMINATED AREA

- SOIL (B,S). WATER(W), VEGETATION (V) SAMPLES

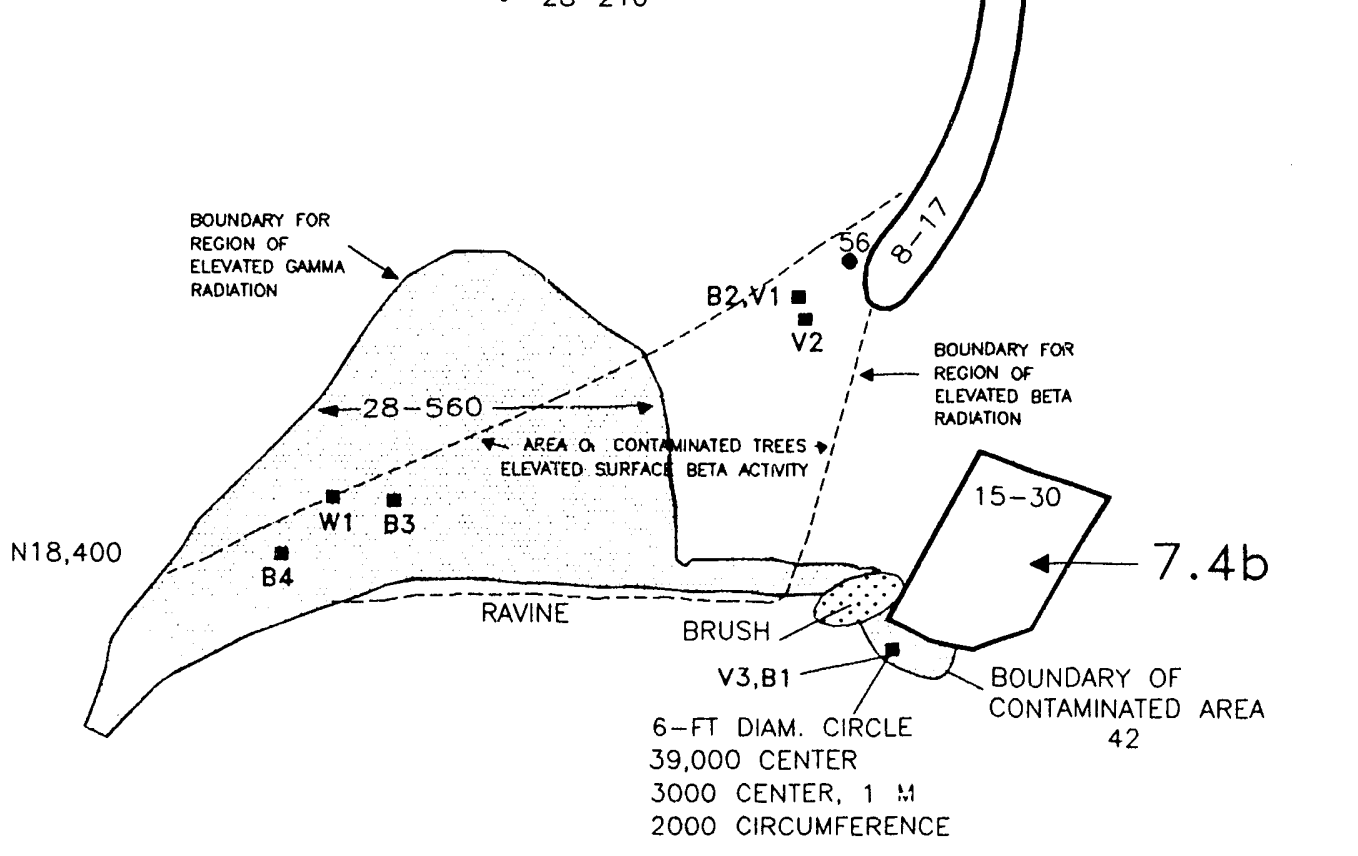

$E 27,800$

$E 28,000$

Fig. 12. Diagram showing results of surface radiological survey and locations of environmental samples at Trench 6 and LLW Line Leak Site 7.4b. Surface gamma exposure rates, measured with a $\mathrm{NaI}$ sciniillator or closed-window GMSM, are given in microroentgens per hour. 


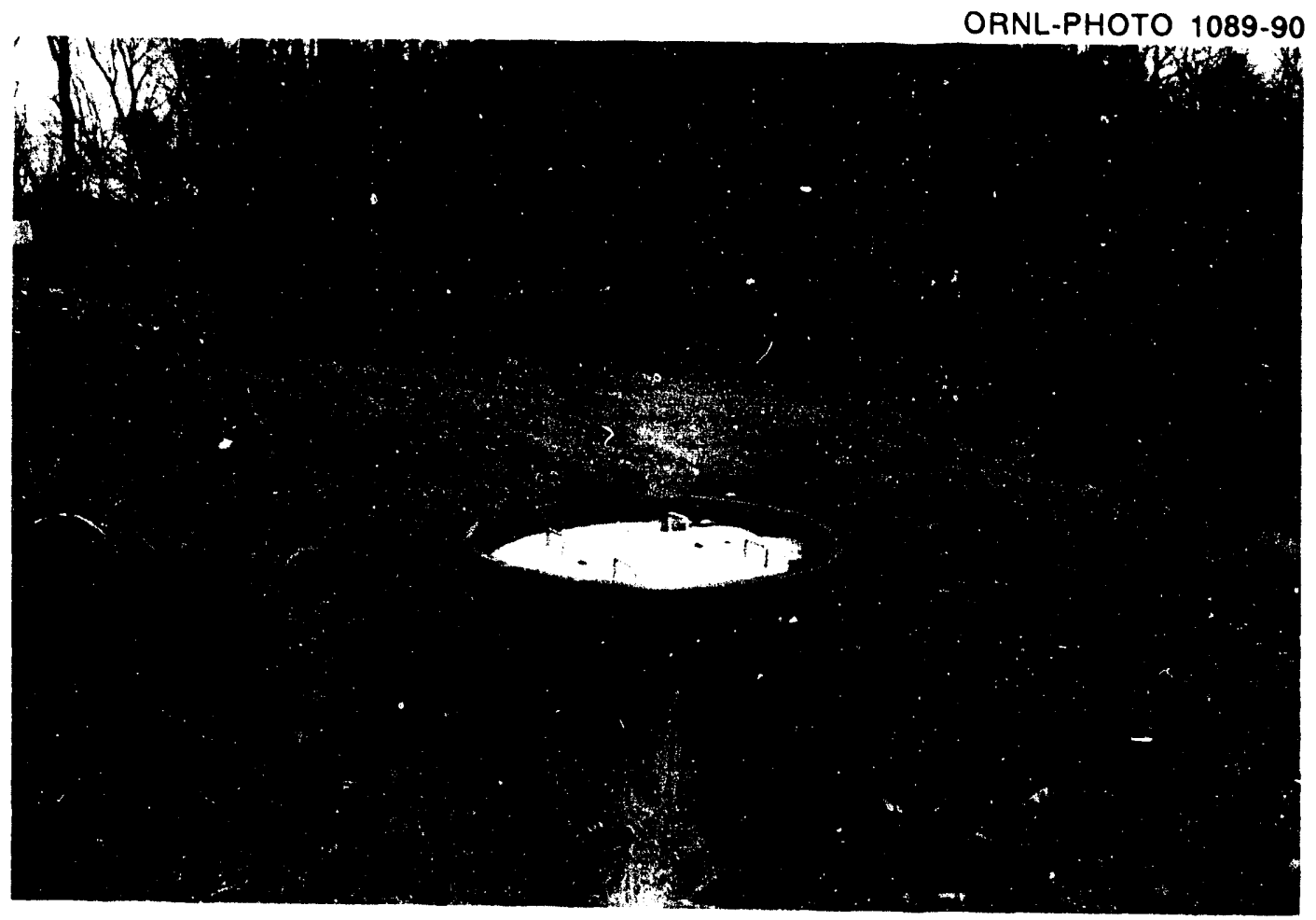

Fig. 13. View of terra-cotta pipe located north of Trench 6 (January 1990). A faded radiation hazard sign is located between the two handles on the right side of the metal cover.

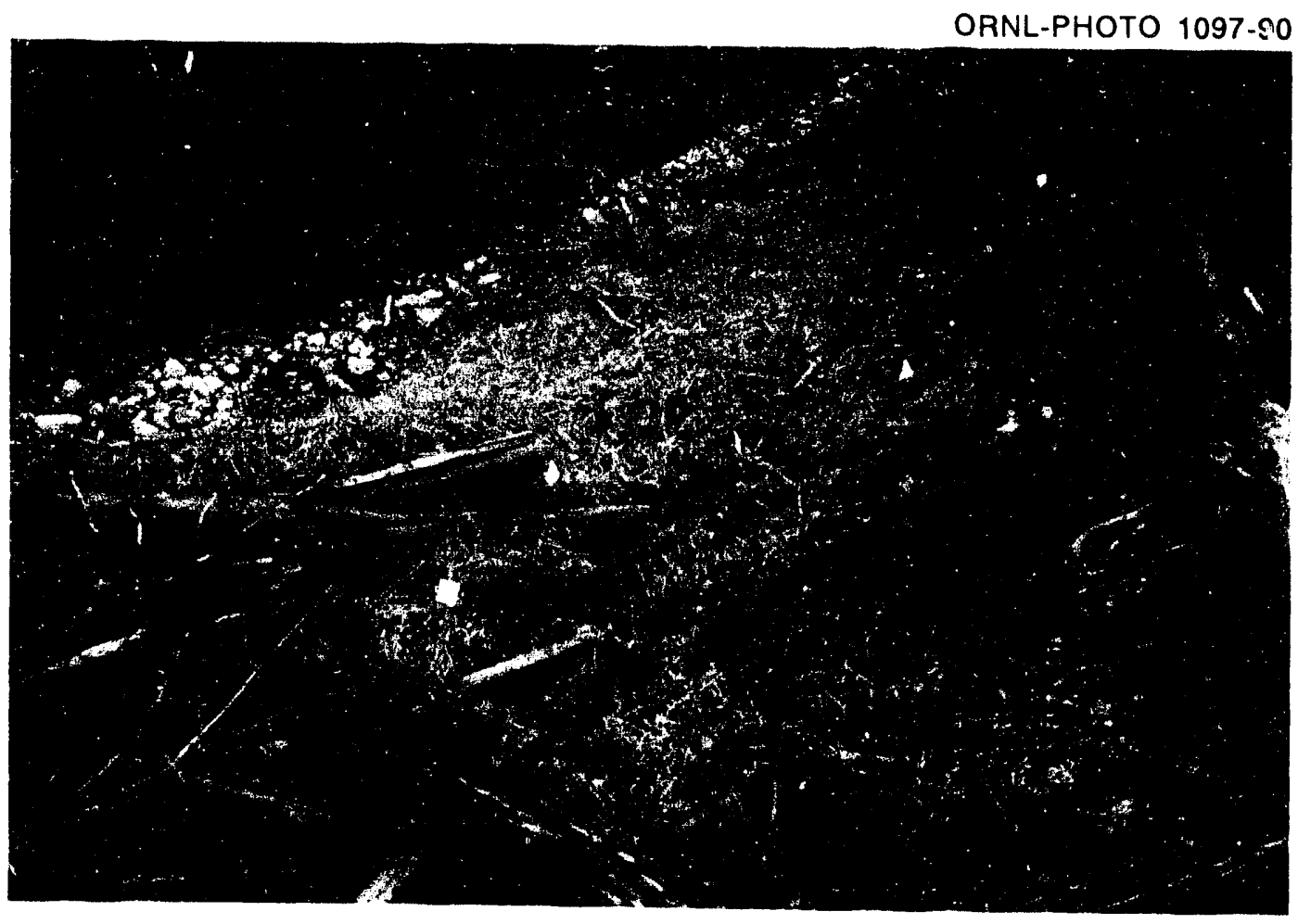

Fig. 14. Vicw of hot spot just south of LLW Line Leak Site $7.4 \mathrm{~b}$ (January 1990). Asphalt covering the leak site is visible in the upper left corner of the photo. 


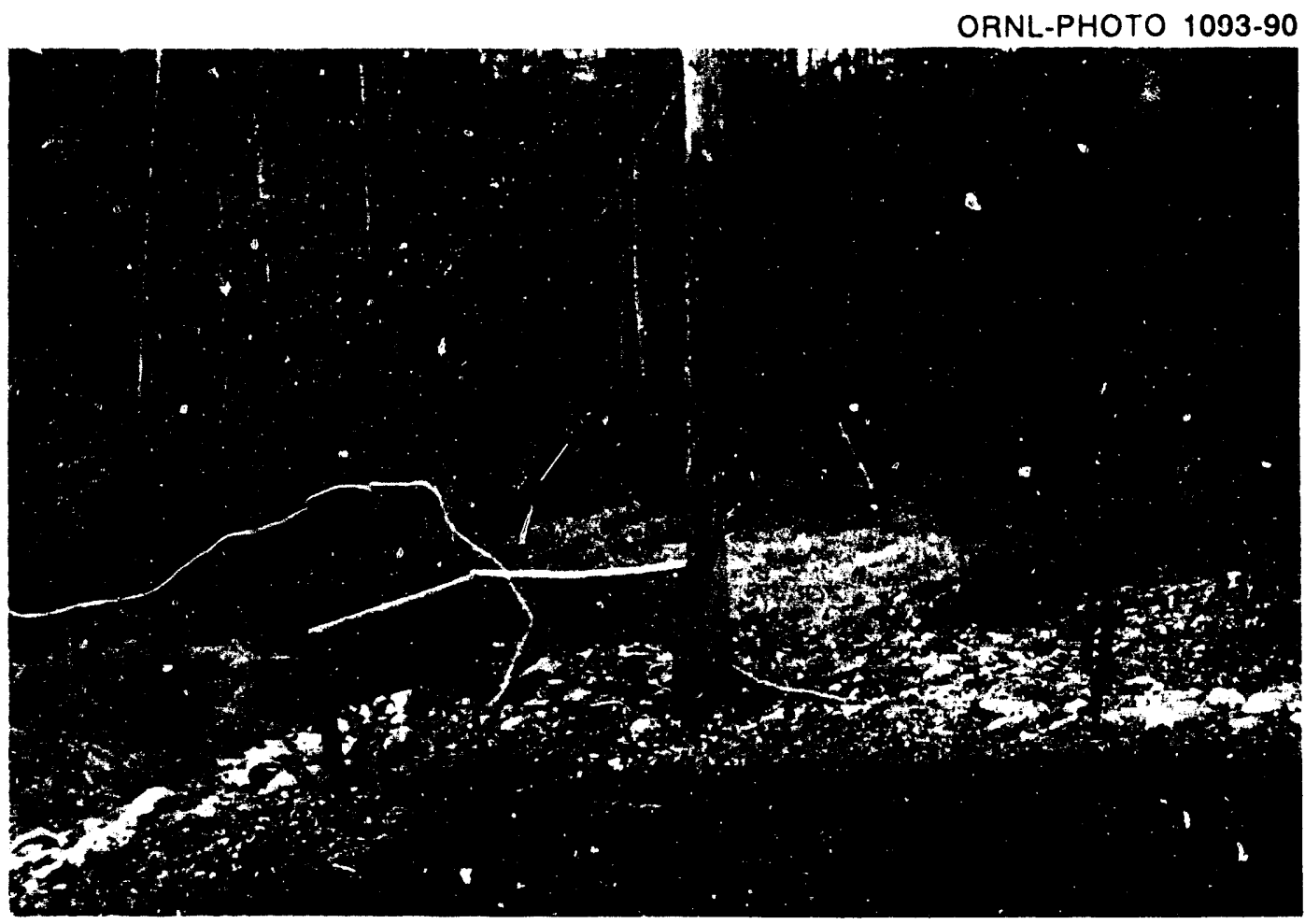

Fig. 15. View of brush at southwest corner of LLW Line Leak Site 7.4b (January 1990). Ravine marking southern survey boundary begins here and extends westward. All detectable surface contamination was located north (to the right) of the ravine.

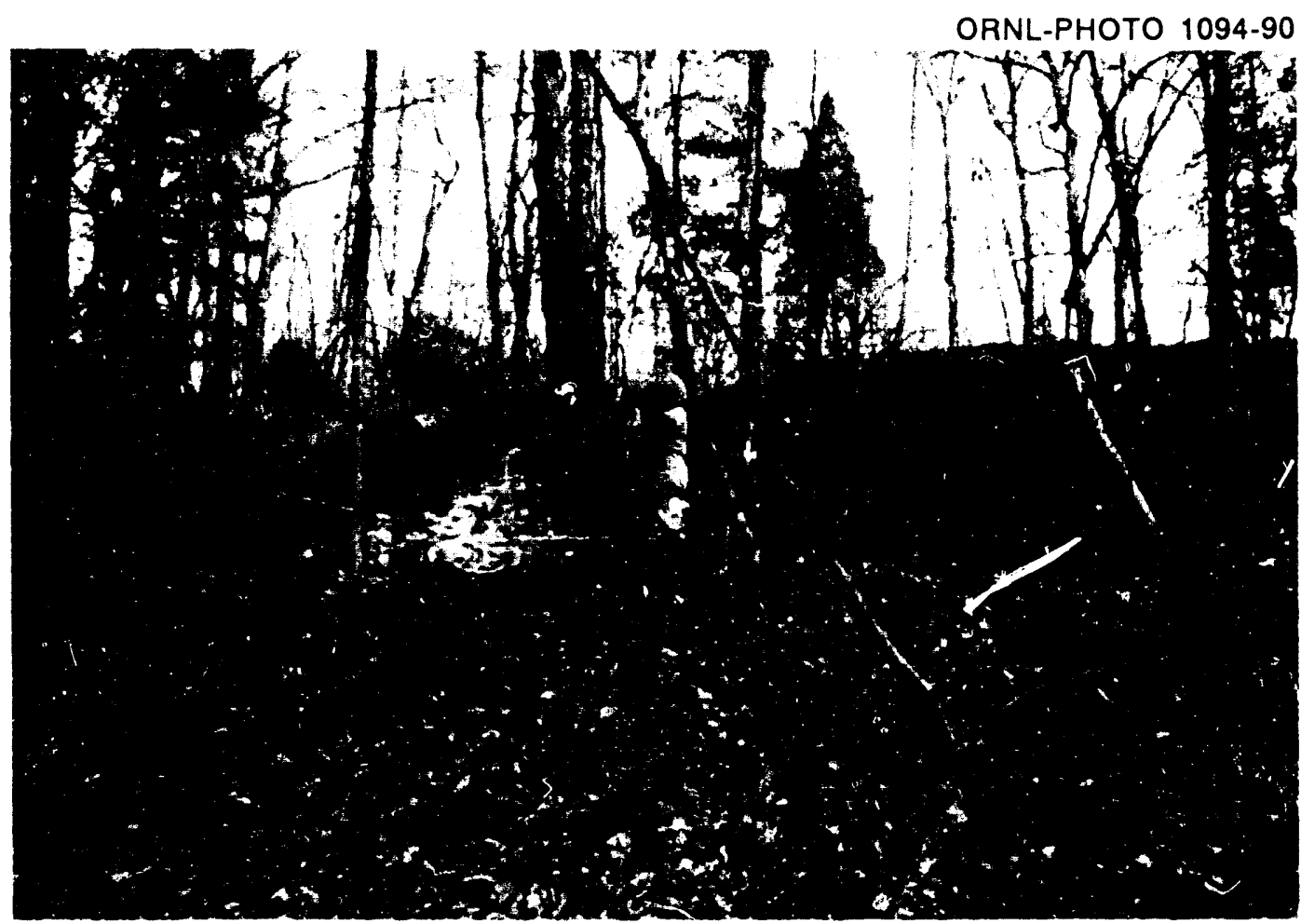

Fig. 16. View looking north at contaminated trees near southwest end of Trench 6 (January 1990). 


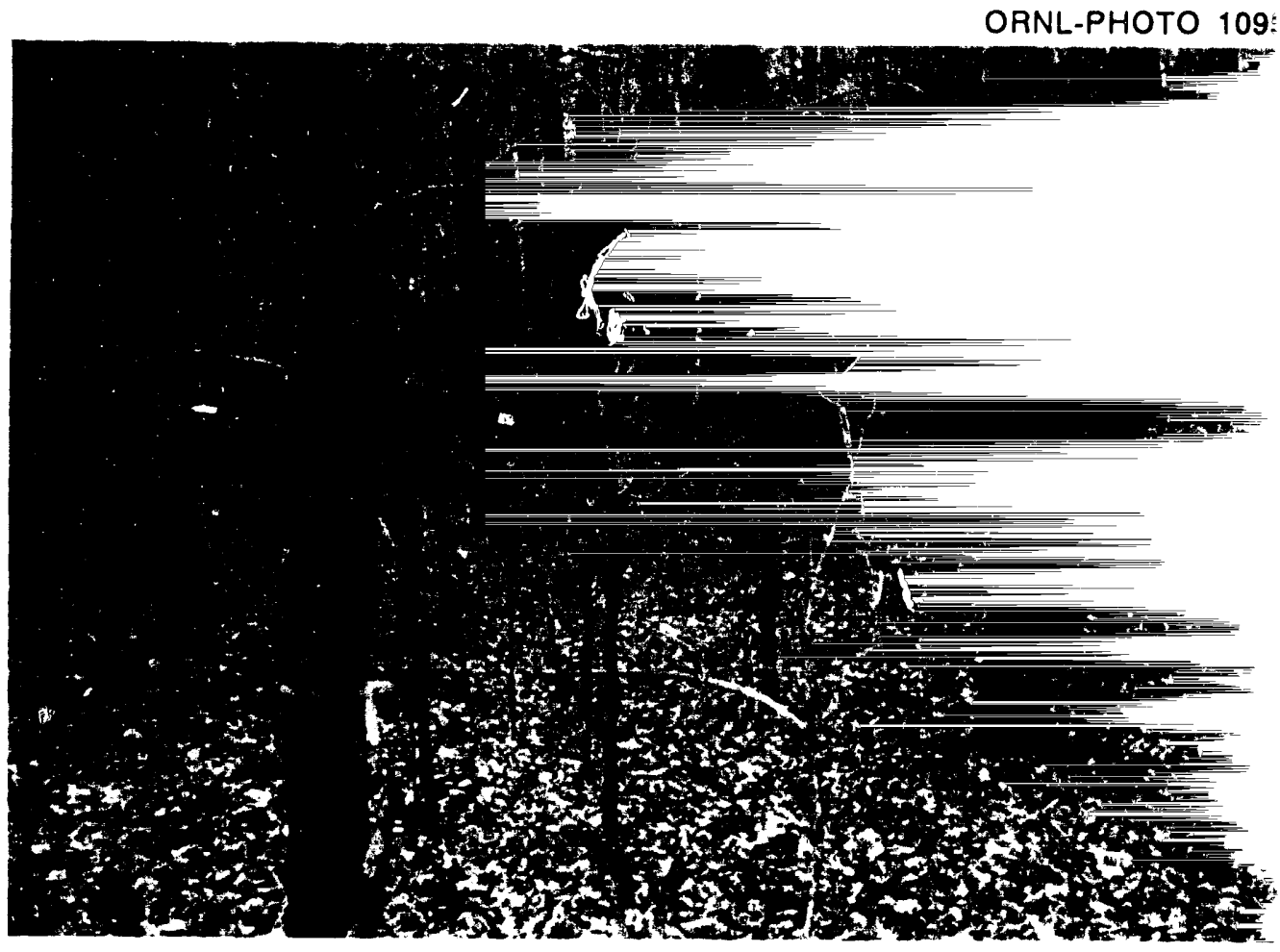

Fig. 17. Vicw from south end of Trench 6 looking southwest at area contaminated trees (January 1990).

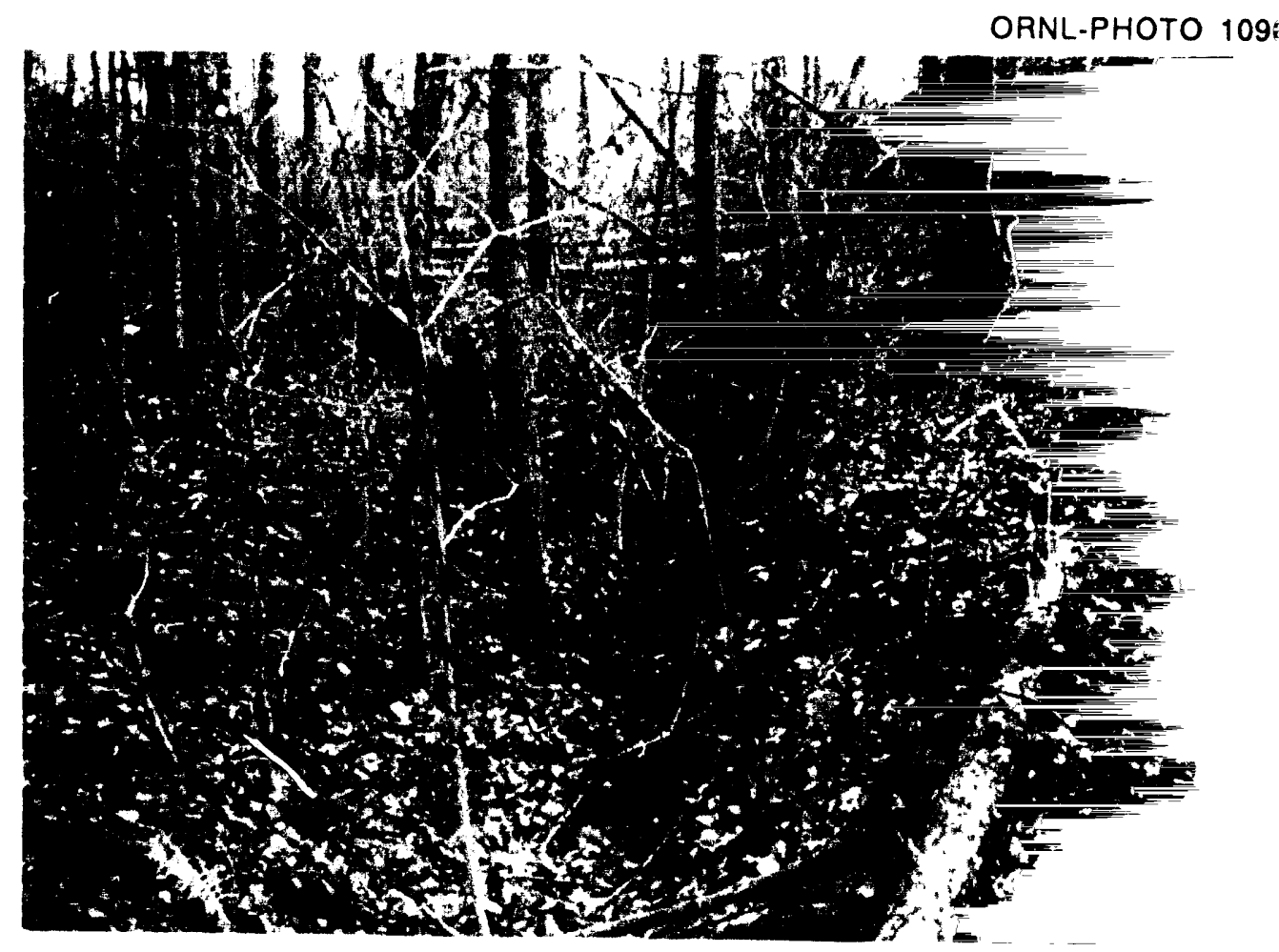

Fig. 18. Vicw looking northcast at ravinc that borders south edge survey site (January 1990). Trees on the north side of the ravine were contaminat no contaminated trees were detected on the south side of the ravine. 
tree trunks. No contaminated trees were found south of the ravine running along the southern survey boundary (Fig. 18).

Early in the survey period when the contaminated trees were first discovered, betagamma levels were measured in a number of trees along the southeast edge of the contaminated area. These measurements are given in Table 1 . This is a small representative sample; counts were not recorded for every contaminated tree. The $17-\mathrm{mrad} / \mathrm{h}$ tree was located west of the south end of Trench 6 near sample locations B2, V1, and V2 shown on Fig. 12.

\subsection{SOIL SAMPLE ANALYSES}

Results of soil sample analysis are given in Table 2, and collection locations are indicated on Fig. 12. Samples B1A, B1B, and B1C were composed of wood chips mixed

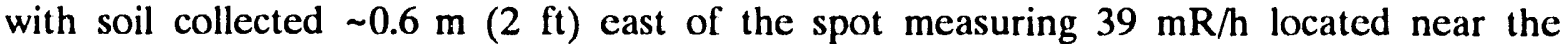
southwest corner of Leak Site 7.4b. Sample B1A contained $8500 \mathrm{pCi} / \mathrm{g}{ }^{137} \mathrm{Cs}$ and $77,000 \mathrm{pCi} / \mathrm{g}$ gross beta activity. Sample B1B contained less ${ }^{137} \mathrm{Cs}(7900 \mathrm{pCi} / \mathrm{g})$ but more gross beta activity $(81,000 \mathrm{pCi} / \mathrm{g})$, suggesting that the beta activity is from another radionuclide, probably ${ }^{90} \mathrm{Sr}$. Surface gamma levels* reached $39 \mathrm{mR} / \mathrm{h}$ in the area, but at the soil sample hole, gamma levels ranged from $19 \mathrm{mR} / \mathrm{h}$ at a depth of $30 \mathrm{~cm}$ (12 in.) to $32 \mathrm{mR} / \mathrm{h}$ at the surface. Beta-gamma dose rates measured $40 \mathrm{mrad} / \mathrm{h}$ at the sample location. Surface alpha was below the minimum detectable activity of the instrument.

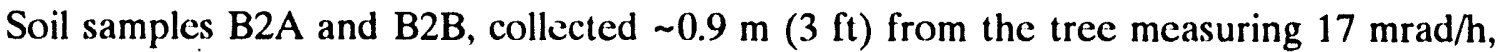
contained 1500 and $380 \mathrm{pCi} / \mathrm{g}$ gross beta activity, respectively. The soil was originally covered with dry leaves exhibiting gamma levels of $21 \mu \mathrm{R} / \mathrm{h}$ and beta-gamma levels of $1.6 \mathrm{mrad} / \mathrm{h}$. Soil gamma levels measured $21 \mu \mathrm{R} / \mathrm{h}$ at the surface and at $5 \mathrm{~cm}(2 \mathrm{in}$.$) and$ $17 \mu \mathrm{R} / \mathrm{h}$ at $15 \mathrm{~cm}(6 \mathrm{in}$.); beta-gamma levels were $0.84 \mathrm{mrad} / \mathrm{h}$ at surface.

Soil samples $\mathrm{B} 3 \mathrm{~A}$ and $\mathrm{B} 3 \mathrm{~B}$, collected in the region of a former seep, contained $1900 \mathrm{pCi} / \mathrm{g}$ gross beta activity, 62.0 to $680 \mathrm{pCi} / \mathrm{g}{ }^{90} \mathrm{Sr}, 350 \mathrm{pCi} / \mathrm{g}{ }^{137} \mathrm{Cs}$, and $300 \mathrm{pCi} / \mathrm{g}{ }^{60} \mathrm{Co}$. Gamma exposure rates at $1 \mathrm{~m}$ measured $98 \mu \mathrm{R} / \mathrm{h}$; gamma exposure rates at the surface and at 15- and 30-cm (6- and 12-in.) depths in the sample hole measured 420, 500, and $560 \mu \mathrm{R} / \mathrm{h}$, respectively. Beta-gamma dose rates were $1.8 \mathrm{mrad} / \mathrm{h}$ at the surface.

Soil sample $\mathrm{B} 4$ contained $22 \mathrm{pCi} / \mathrm{g}{ }^{137} \mathrm{Cs}$. Gamma exposure rates reached $35 \mu \mathrm{R} / \mathrm{h}$ at $1 \mathrm{~m}, 28 \mu \mathrm{R} / \mathrm{h}$ at the surface, and 21 at a depth of $5 \mathrm{~cm}(2 \mathrm{in}$.). Beta-gamma dose rates measured $0.21 \mathrm{mrad} / \mathrm{h}$ at the surface. Surface alpha was below the minimum detectable activity of the instrument.

\footnotetext{
*Barium-137m, a gamma emitter, is the short-lived decay product of the beta-emitter ${ }^{137} \mathrm{Cs}$.
} 
Table 1. Beta-gamma radiation levels measured on tree trunks in the vicinity of Trench 6 and LLW Line Leak Site 7.4b

\begin{tabular}{|c|c|c|}
\hline \multicolumn{2}{|c|}{ Beta-gamma levels ${ }^{a}(\mathrm{mrad} / \mathrm{h})$} & \multirow[b]{2}{*}{ Comments } \\
\hline Tree trunk ${ }^{b}$ & $\mathrm{Air}^{\mathrm{C}}$ & \\
\hline 1.0 & 0.13 & $\begin{array}{l}\text { Young maple, }-1 \text { in. diam, near } \\
\text { east edge of contaminated area }\end{array}$ \\
\hline 0.62 & 0.093 & $\begin{array}{l}\text { Tree with elm-like leaves, } \sim 1.5 \text { in. } \\
\text { diam }\end{array}$ \\
\hline 1.2 & 0.08 & $\begin{array}{l}\text { Tree with elm-like leaves, } \sim 2.5 \text { in. } \\
\text { diam, near east edge of } \\
\text { contaminated area }\end{array}$ \\
\hline 1.1 & 0.095 & $\begin{array}{l}\text { Tree with elm-like leaves, } \sim 1.5 \mathrm{in} \text {. } \\
\text { diam, east edge of contaminated } \\
\text { area }\end{array}$ \\
\hline 2.6 & 0.16 & $\begin{array}{l}\text { Maple, } \sim 8 \text { in. diam, southeast edge } \\
\text { of contaminated area }\end{array}$ \\
\hline 1.4 & 0.10 & $\begin{array}{l}\text { Maple, } ~-13 \text { in. diam, southeast } \\
\text { edge of contaminated area }\end{array}$ \\
\hline 3.3 & 0.18 & $\begin{array}{l}\text { Maple, } \sim 1 \text { in. diam, southeast edge } \\
\text { of contaminated area near drainage } \\
\text { ditch }\end{array}$ \\
\hline 1.8 & 0.13 & $\begin{array}{l}\text { Tree with elm-like leaves, } \sim 5 \text { in. } \\
\text { diam, southeast edge of } \\
\text { contaminated area in drainage ditch }\end{array}$ \\
\hline 3.3 & 0.15 & $\begin{array}{l}\text { Remains of tree, }-7.5 \text { in. diam, still } \\
\text { upright, southeast edge of } \\
\text { contaminated area on lip of ditch }\end{array}$ \\
\hline 3.0 & 0.41 & $\begin{array}{l}\text { Base of maple tree measured } \sim 8 \text { in. } \\
\text { above ground surface, tree } \sim 3 \text { in. } \\
\text { diam }\end{array}$ \\
\hline 3.0 & 0.14 & $\begin{array}{l}\text { Large, old maple, } \sim 20 \text { in. diam, } \\
\text { east side of ditch parallel to black } \\
\text { drain pipes }\end{array}$ \\
\hline 0.21 & 0.077 & $\begin{array}{l}\text { Small maple, } \sim 35 \mathrm{ft} \text { southwest of } \\
\text { southwest corner of Tench } 6\end{array}$ \\
\hline 0.70 & 0.065 & $\begin{array}{l}\text { Elm-like tree, }-10 \mathrm{ft} \text { south of small } \\
\text { maple described directly above }\end{array}$ \\
\hline
\end{tabular}


Table 1 (continued)

\begin{tabular}{|c|c|c|}
\hline \multicolumn{2}{|c|}{ Beta-gamma levels $^{a}(\mathrm{mrad} / \mathrm{h})$} & \multirow[b]{2}{*}{ Comments } \\
\hline Tree trunk $k^{b}$ & $\mathrm{Air}^{\mathrm{C}}$ & \\
\hline 1.1 & 0.072 & $\begin{array}{l}\text { Maple, }-2.5 \text { in. diam, south of elm- } \\
\text { like tree described directly above }\end{array}$ \\
\hline 17 & 0.028 & $\begin{array}{l}\text { Elm-like tree, } \sim 2 \text { in. diam, } \sim 20 \mathrm{ft} \\
\text { southwest of southwest corner of } \\
\text { Trench } 6\end{array}$ \\
\hline
\end{tabular}

${ }^{a}$ Shielded readings on tree showed no gamma activity.

${ }^{b}$ Measured with GM pancake probe on contact with tree trunk. All measurements taken at breast height except one (noted in comments).

${ }^{c}$ Measured with pancake probe held $\sim 12$ in. from tree trunk, back of detector facing tree. 


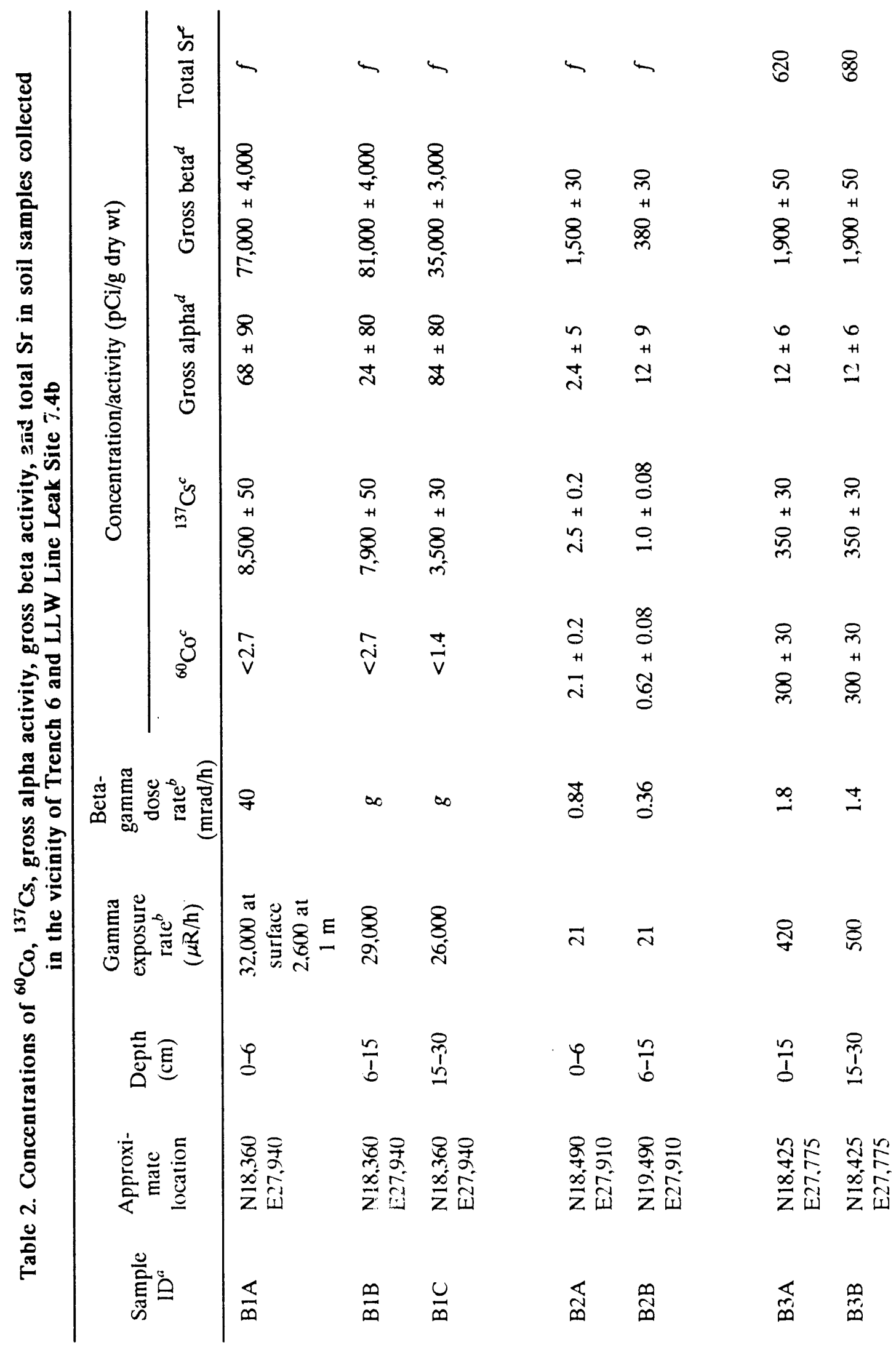




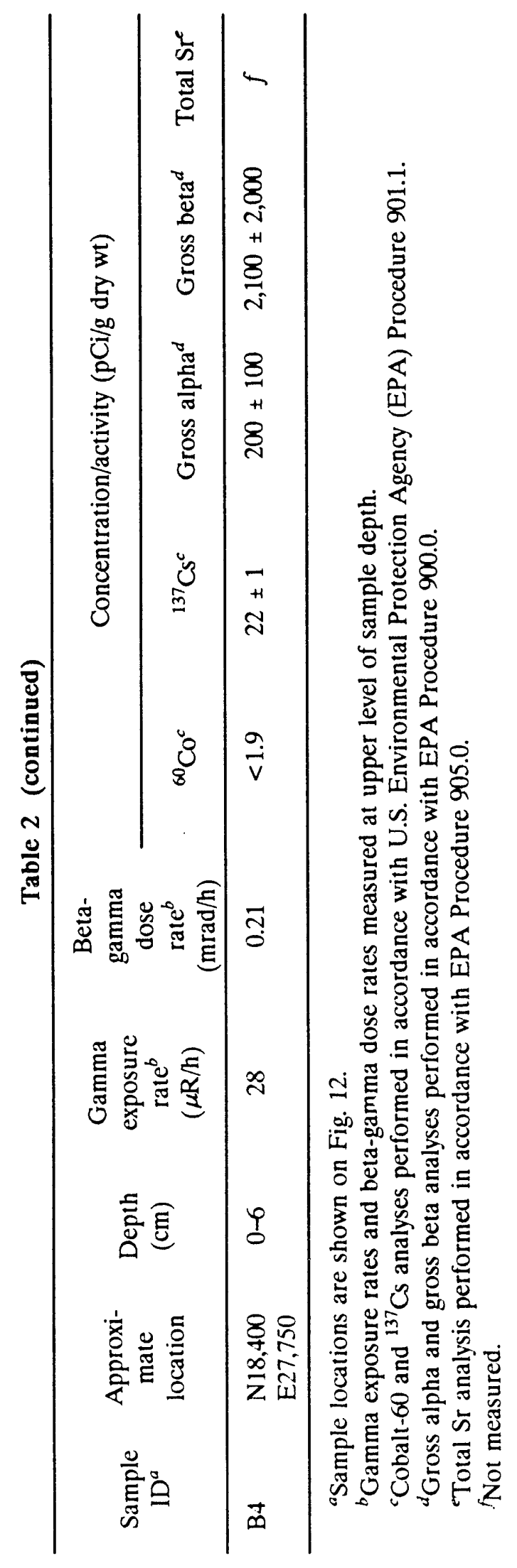




\subsection{VEGETATION SAMPLE ANALYSES}

Results of vegetation analysis are shown in Table 3, and vegetation sample locations are indicated on Fig. 12 by the letter V. A sample of dried leaves (V1), collected near the tree that measured $17 \mathrm{mrad} / \mathrm{h}$, contained $6500 \mathrm{pCi} / \mathrm{g}$ gross beta activity, $3.2 \mathrm{pCi} / \mathrm{g}{ }^{60} \mathrm{Co}$, and $1.1 \mathrm{pCi} / \mathrm{g}{ }^{137} \mathrm{Cs}$. The surface of the dried leaves showed gamma levels of $21 \mu \mathrm{R} / \mathrm{h}$ and beta-gamma levels of $1.6 \mathrm{mrad} / \mathrm{h}$.

Fresh leaves (V2 on Fig. 12) from a second tree located near the $17-\mathrm{mrad} / \mathrm{h}$ tree contained $8100 \mathrm{pCi} / \mathrm{g}$ gross beta activity and $2.6 \mathrm{pCi} / \mathrm{g}{ }^{60} \mathrm{Co}$. (Fresh leaves on the $17-\mathrm{mrad} / \mathrm{h}$ tree were out of reach.) Beta-gamma dose rates measured on the surface of the collected leaves reached $3.8 \mathrm{mrad} / \mathrm{h}, 25$ times typical levels measured in this region of $0.15 \mathrm{mrad} / \mathrm{h}$.

Samples of grass and weeds (V3), collected near the $39-\mathrm{mR} / \mathrm{h}$ spot by LLW Line Leak Site $7.4 \mathrm{~b}$, contained $1100 \mathrm{pCi} / \mathrm{g}$ gross beta activity, $0.32 \mathrm{pCi} / \mathrm{g}{ }^{60} \mathrm{Co}$, and $2.7 \mathrm{pCi} / \mathrm{g}{ }^{137} \mathrm{Cs}$. The sampled vegetation measured $140 \mu \mathrm{R} / \mathrm{h}$ and $0.53 \mathrm{mrad} / \mathrm{h}$, gamma and beta-gamma, respectively.

\subsection{WATER SAMPLE ANALYSES}

A water sample collected $\sim 52 \mathrm{~m}(170 \mathrm{ft})$ southwest of Trench $6 \mathrm{newr}$ an abandoned pump (Fig. 19) contained $3800 \pm 300 \mathrm{pCi} / \mathrm{L}$ gross beta activity, $270 \pm 30 \mathrm{pCi} / \mathrm{L}{ }^{137} \mathrm{Cs}$, $23 \pm 10 \mathrm{pCi} / \mathrm{L}{ }^{60} \mathrm{Co}$, and $3.8 \pm 3 \mathrm{pCi} / \mathrm{L}$ gross alpha. Surface gamma exposure rates near the collection point measured $280 \mu \mathrm{R} / \mathrm{h}$. The water sample location is identified on Fig. 12 by the letter W. No surface contamination was detected on the pump. Two weather-beaten contamination zone signs mark this area, possibly the location of a former seep. 


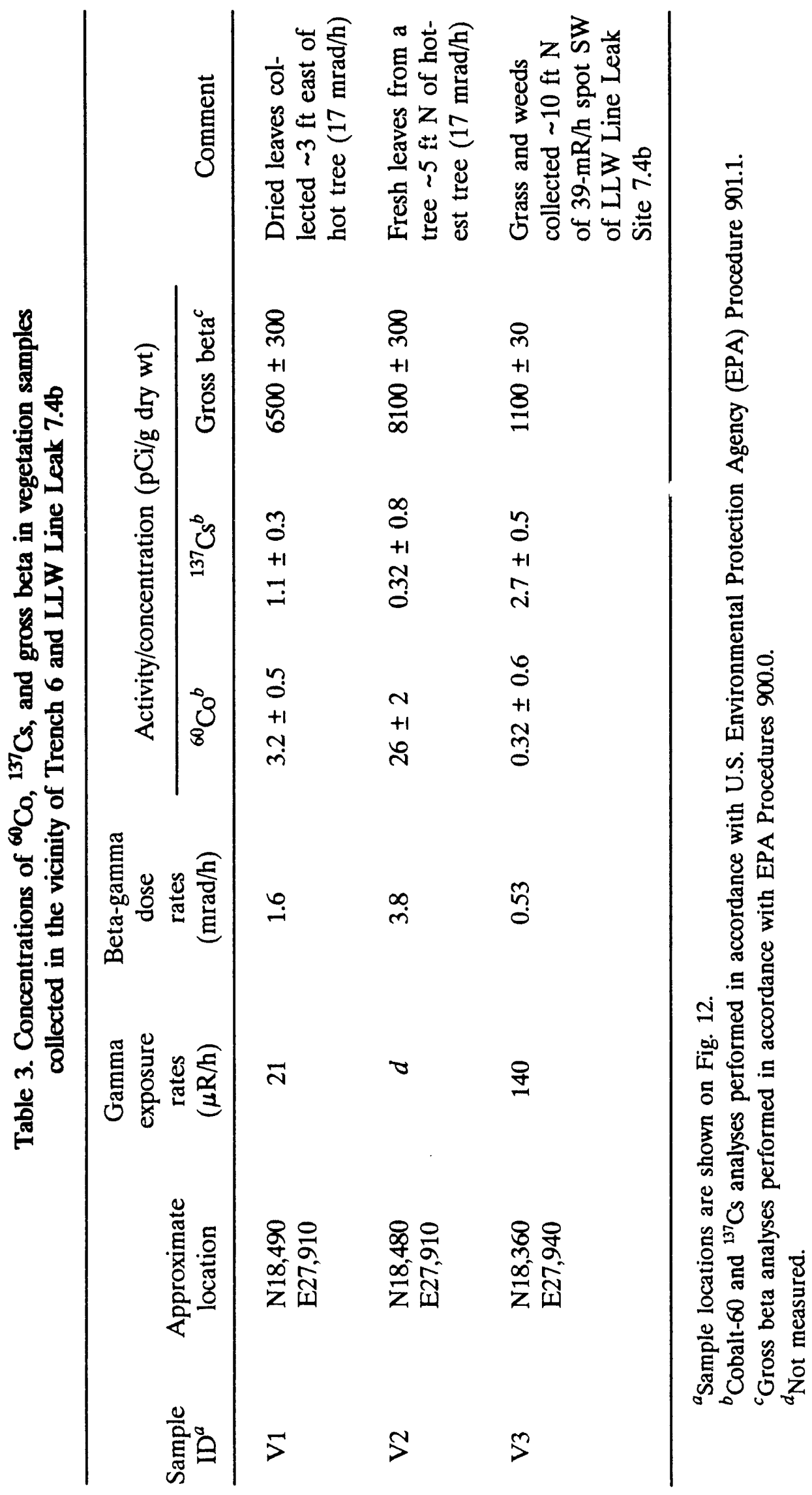




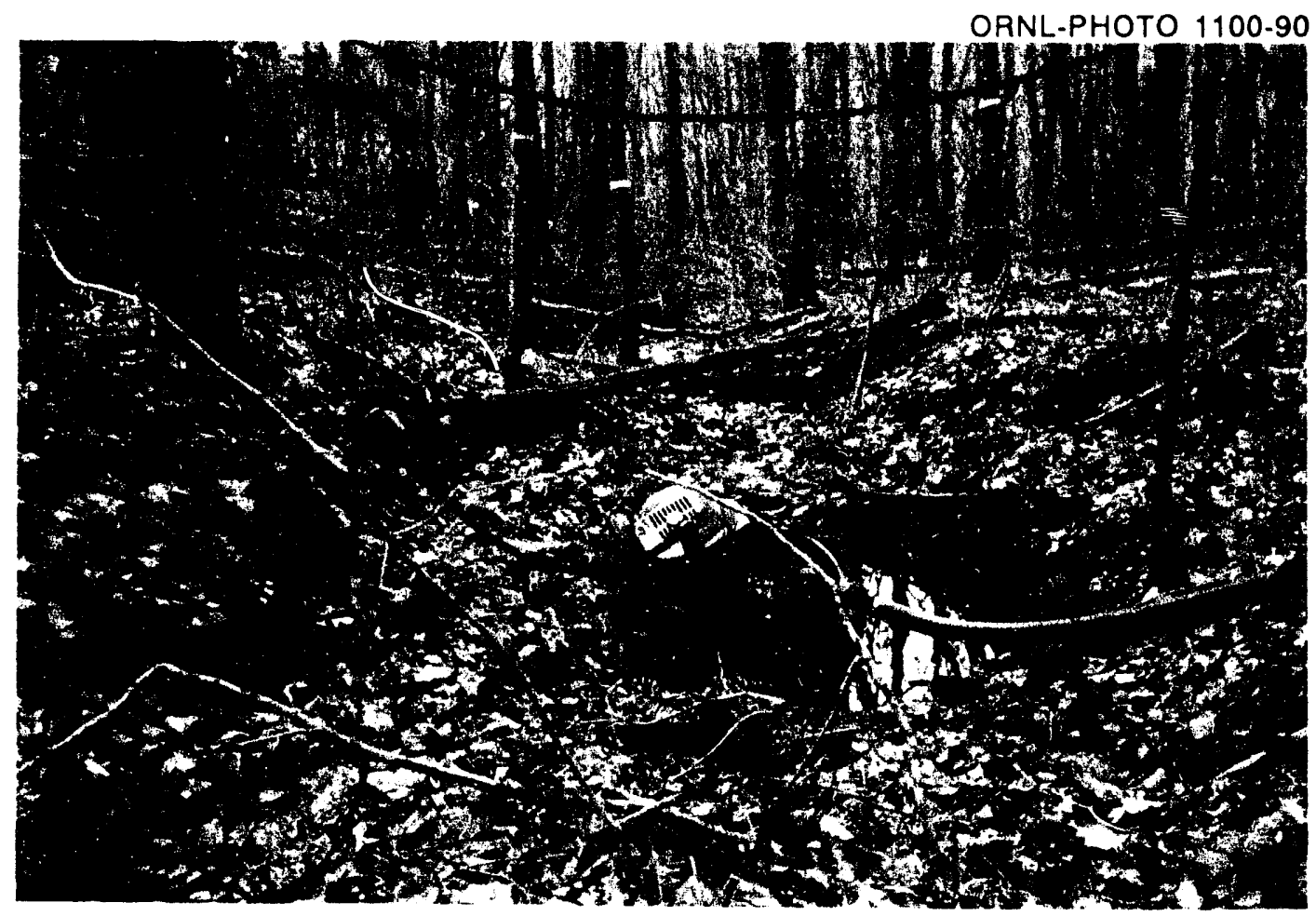

Fig 19. View showing abandoned pump located in the area of former seep (January 1990). A water sample from pool beside pump contained beta activity. 


\section{SIGNIFICANCE OF FINDINGS}

Highest surface radiation levels encountered during the survey were found outside fenced, placarded contamination zones just south of LLW Line Leak Site 7.4b. At this location, surface gamma levels reached $39,000 \mu \mathrm{R} / \mathrm{h}$ and $1-\mathrm{m}$ levels measured $3000 \mu \mathrm{R} / \mathrm{h}$. The $1-\mathrm{m}$ measurement is 300 times the average gamma level $(10 \mu \mathrm{R} / \mathrm{h})$ found in uncontaminated areas on the Oak Ridge Reservation. Elevated gamma levels were previously detected in this area during a scoping investigation in August 1987. At that time, the current area of concern was covered with cut trees, vegetative debris, and fill dirt (Fig. 20). This debris has since been moved and relocated to the west, making the area more accessible for surface radiation measurement. Figures 10 and 20 depict site conditions during the 1987 and 1990 surveys, respectively. Figure 12 shows the current location of the brush pile.

Soil samples in the contaminated area south of Leak Site $7.4 \mathrm{~b}$ contained up to $81,000 \mathrm{pCi} / \mathrm{g}$ gross beta activity* and $8500 \mathrm{pCi} / \mathrm{g}{ }^{137} \mathrm{Cs}$, indicating that another beta emitter, most likely ${ }^{90} \mathrm{Sr}$, is primarily responsible for the beta activity. A vegetation sample from the area contained $1100 \mathrm{pCi} / \mathrm{g}$ gross beta activity but only $2.7 \mathrm{pCi} / \mathrm{g}{ }^{137} \mathrm{Cs}$, supporting this hypothesis. (Strontium analysis is costly and could not be justified for all samples.)

The most significant finding of this survey was the large area of trees with elevated beta levels $(0.21$ to $17 \mathrm{mrad} / \mathrm{h})$ suggesting that tree roots are reaching contamination deep within the ground. The contaminated trees cover the area between Trench 6 and the former seep, which contained significant levels of ${ }^{90} \mathrm{Sr}$ and ${ }^{137} \mathrm{Cs}$ when first discovered in 1961 . No gamma radiation was detected on the trees or leaves, indicating that ${ }^{137} \mathrm{Cs}$ is not involved; therefore, the elevated beta levels of the trees are probably caused by the uptake of underground ${ }^{90} \mathrm{Sr}$. Strontium-90 acts as an analog of calcium, which is readily taken up by vascular plants. Furthermore, it has been reported that trees may concentrate ${ }^{90} \mathrm{Sr}$ more readily than other plant species. ${ }^{4}$

Leaves from the trees appear to be depositing significant beta activity on the ground surface. Beta activity was found in dried leaves $(6500 \mathrm{pCi} / \mathrm{g})$; fresh leaves $(8100 \mathrm{pCi} / \mathrm{g})$, and surface soil $(1500 \mathrm{pCi} / \mathrm{g})$. Soil collected 6 to $15 \mathrm{~cm}$ below the surface contained much less beta activity $(350 \mathrm{pCi} / \mathrm{g})$, suggesting that soil contamination is coming from decaying leaves. Leak Site $7.4 \mathrm{~b}$ probably contributed to the large area of elevated surface gamma levels (28 to $560 \mu \mathrm{R} / \mathrm{h}$ ) that overlaps the area with elevated beta radiation levels.

The area presumed to be the location of the former seep is marked by weathered contamination zone signs but not by rope or fencing. Surface gamma levels at sample points in the former seep area measured 280 and $420 \mu \mathrm{R} / \mathrm{h}$; soil contained gross beta activity

\footnotetext{
*Uncontaminated soil on the Oak Ridge Reservation normally contains 15 to $40 \mathrm{pCi} / \mathrm{g}$ gross beta activity. (J. W. Wade, Analytical Chemistry Division, Oak Ridge Natl. Lab., personal communication to M. S. Uziel, Health and Safety Research Division, Oak Ridge Natl. Lab., September 1989.)
} 
(1900 pCi/g), Sr $(680 \mathrm{pCi} / \mathrm{g}),{ }^{137} \mathrm{Cs}(350 \mathrm{pCi} / \mathrm{g})$, and ${ }^{60} \mathrm{Co}(300 \mathrm{pCi} / \mathrm{g})$. A water sample in the seep area contained beta activity $(3800 \mathrm{pCi} / \mathrm{L})$ and ${ }^{137} \mathrm{Cs}(270 \mathrm{pCi} / \mathrm{L})$ at 27 and 19 times levels normally found in uncontaminated groundwater in the Oak Ridge area.*

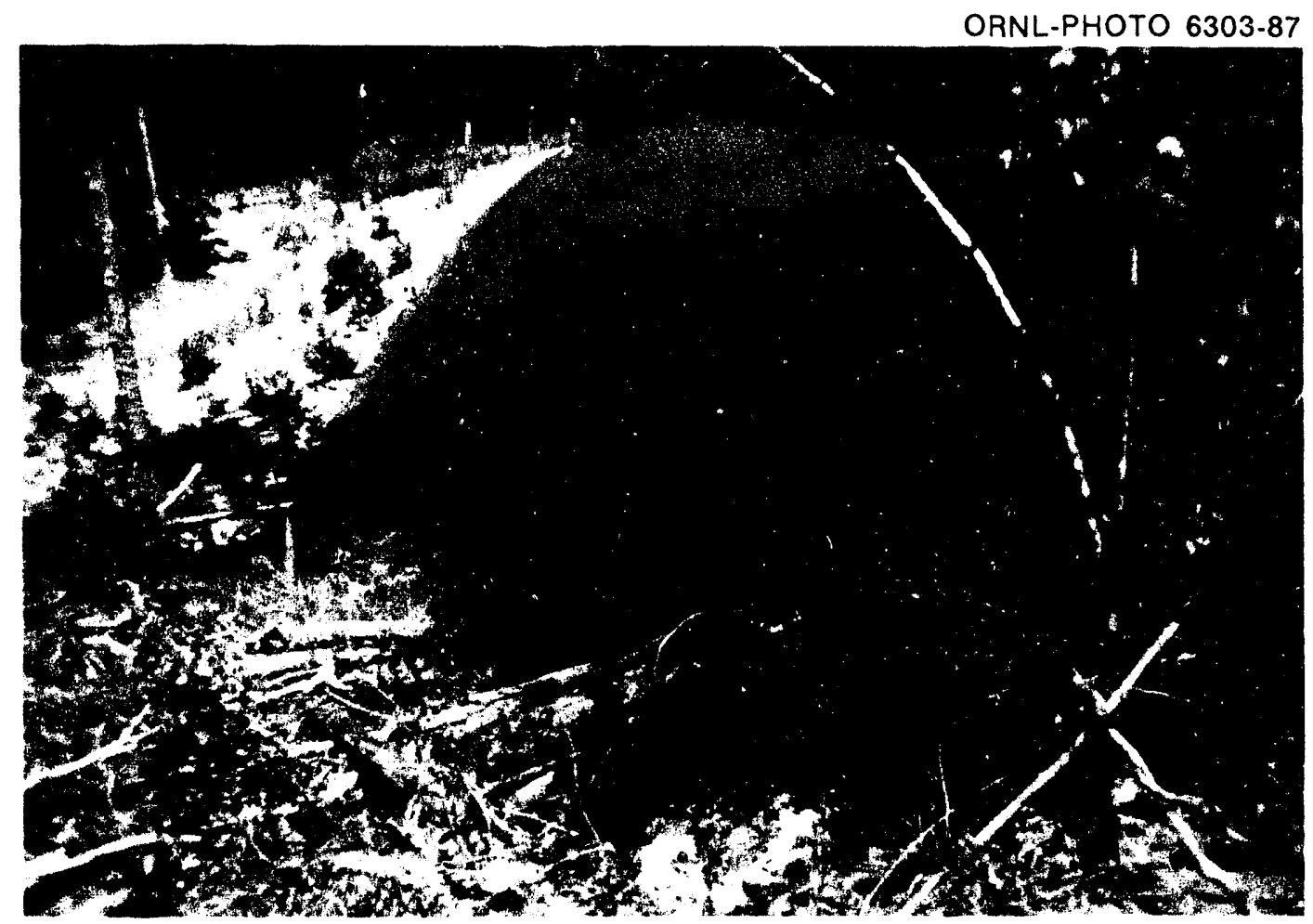

Fig. 20. View looking north at LLW Linc Leak Site 7.4b (August 1987).

*Uncontaminated groundwater in the Oak Ridge area usually contains $<140 \mathrm{pCi} / \mathrm{L}$ gross beta and $<14 \mathrm{pCi} / \mathrm{L}{ }^{137} \mathrm{Cs}$. (J. W. Wade, Analytical Chemistry Department, Oak Ridge Natl. Lab., personal communication to M. S. Uziel, Health and Safety Research Division, Oak Ridge Natl. Lab., September 1989.) 


\section{RECOMMENDATIONS FOR CORRECTIVE ACTIONS}

The presence of elevated gamma radiation levels at the ground surface; verified gross beta activity in sampled soil, leaf litter, and undercover vegetation; and the identification of contaminated trees exhibiting elevated beta activity levels warrant immediate corrective actions. This conclusion is based solely on the results of this survey, which should be considered an interim assessment pending a more detailed, radiological characterization of the Trench 6/Leak Site 7.4b area. Because a scoping survey is considered a limited, cursory investigation, the radiological data and subsequent assessment of data presented in this report should be considered only a "snapshot" radiological representation of the site during the dates of the survey.

Two basic approaches to interim corrective actions are (1) isolation of contaminated areas (e.g., fencing or roping), including measures to minimize the dispersion and/or redistribution of fugitive radionuclides, and (2) removal, treatment (if required) and disposal of contaminated material (e.g., soil, leaf litter, undercover vegetation), and subsequent stabilization of the treated areas. Health risk assessments should be conducted and used in the evaluation of remedial action options. Because high concentrations of radionuclides $\left[{ }^{137} \mathrm{Cs}\right.$ and gross beta activity (most likely ${ }^{90} \mathrm{Sr}$ )] were confirmed in sampled soil and indigenous vegetation, the removal, treatment, and disposal of contaminated waste may pose a greater health risk than leaving it in situ. A "leave-in-place" option, coupled with the application of proven, demonstrable technologies for long-term stabilization and/or reduction of radiation exposures, should be considered for highly contaminated areas. Several contaminated hot spots and one large area of land exhibiting elevated surface gamma radiation levels and beta activity levels (see Fig. 12) were identified at locations near Trench 6. Radiation control measures outlined by ORNL Health Physics should be implemented at these locations. Additionally, spot remediation should be considered for some localized hot-spot land areas.

The problem of contaminated trees and other aboveground forest biomass presents itself as one of the most delicate issues in corrective and/or remedial action planning. The basic dilemma is striking a reasonable balance between the extent of cleanup and probable disturbance to the forest/watershed ecosystem. It has been strongly suggested that widespread deforestation in the White Oak Creek watershed (i.e., cutting or killing trees) would result in potentially adverse ecological consequences. One such effect is the creation of hydrological disturbances by profoundly increasing precipitation to the area (by approximately $30 \%$ ), possibly increasing runoff, and subsequently, radionuclide migration away from contaminated areas. A second dilemma is an increase in cation leaching $\left(\mathrm{Ca}^{2+}\right)$ from watersheds. One might anticipate an increase in ${ }^{90} \mathrm{Sr}$ leaching from the White Oak Creek drainage to the Clinch River should widespread deforestation occur. However, it is reasonable to recommend targeting "problem trees" (i.c., those trees showing highly elevated surface beta-gamma activity levels with a survey meter) for removal and disposal only on a case-by-case basis. ${ }^{5}$ 
Corrective action options listed below consist of ground-surface measures to limit human exposures, minimize surficial dispersion of radiological contamination, and monitor any such dispersion. Not every contamination situation would involve the implementation of all recommendations listed below; rather, the recommendations should be considered individually or in appropriate combinations. A more detailed investigation (with core hole borings and soil analysis) woulc' be required to fully characterize the radiological status of the Trench 6/Leak Site 7.4b area and to address the most appropriate methods for effective, long-term remediation. The primary concern in assessing appropriate corrective actions is the minimization of exposures of personnel to radiation. These recommendations are in accordance with the radiation safety policy of ORNL to conduct all operations in such a manner that personnel exposures to radiation are maintained at a level as low as reasonably achievable (ALARA).

It is not within the scope of this investigation to identify and/or correlate federal and state environmental laws and their applicability for a suggested corrective action; however, it is important to mention that any removable and/or remedial action at the Trench 6/Leak Site $7.4 \mathrm{~b}$ area must be in accord with applicable federal and state laws and DOE orders. The reference section includes two detailed sources listing major environmental laws ${ }^{6}$ and proposed guidance for remedial action strategies at sites previously contaminated with radioactive materials at ORNL. ${ }^{7}$

\section{Isolation of contaminated areas}

- Gamma exposure rate measurements outside the fenced, placarded contamination zone immediately south of the Leak Site $7.4 \mathrm{~b}$ (Fig. 12) revealed $3 \mathrm{mR} / \mathrm{h}$ at $1 \mathrm{~m}$ from the ground surface (the highest surface reading was $39 \mathrm{mR} / \mathrm{h}$ ). Based on guidelines for establishing contamination control zones developed by ORNL Health Physics, it is recommended that Contamination Area control measures be implemented at this region. The rationale for recommending a "Contamination Area" rather than a "Radiation Area" is that surface radioactivity present at the seep/line leak areas is more highly transferable during wet conditions (e.g., storm events). Contamination control measures including warning signs, definition of zone boundaries, and access control procedures are needed. We recommend that the number of zone portals (point of entrance and exit) be limited to one. In addition, a weatherproof diagram of this area showing radiation levels and localized area of surface contamination should be posted at the zone portal.

- Radiation control measures should be considered for the large contaminated land area exhibiting high surface gamma radiation levels and beta activity levels, including the large area of contaminated trees (see Fig. 12). Warning signs should be posted with instructions to contact the Radiation Protection Section of the Office of Environmental and Health Protection hefore entering the area. Based on recommendations outlined by ORNL Health Physics, "Radiation Hazard-Keep Out" signs would be applicable to this area. This type of warning sign is used primarily to warn the general Laboratory population and the public where access to an area is limited to authorized personnel who have the training necessary to safely perform their job functions within the area. 
- Highly contaminated trees inside the proposed fenced area (noted above) should be identified with yellow or magenta paint, using a predetermined configuration placed at some specific height on the tree trunk. Additionally, the contaminated-trees area should be encircled by a roped or fenced boundary with "Contaminated Foliage" signs attached. This type of sign should specify the radiation hazard and date of such designation.

- The dispersion of fugitive radionuclides by litter fall of contaminated trees poses a significant localized health risk and complex remediation problem. One option to minimize the dispersion of contaminated leaves is to chemically terminate the trees, leave them standing, and periodically monitor contamination in and around the tree areas.

- Gamma radiation measurements revealed levels of $3.2 \mathrm{mR} / \mathrm{h}$ on contact with a metal cover of a terra-cotta pipe located north of Trench 6 (Fig. 12). At this location, gamma levels emanated to $800 \mu \mathrm{R} / \mathrm{h}$ at $1 \mathrm{~m}$ from the pipe. We recommend positioning updated "Radiation Hazard-Keep Out" signs at visible locations outside the perimeter of the emanative area.

- If remedial or cleanup actions are not implemented, active and passive institutional control measures should be maintained for a specified period of time to allow for radioactive decay c $i$ intermediate-lived fission waste products such as ${ }^{90} \mathrm{Sr}$ and ${ }^{137} \mathrm{Cs}$. Long-term institut onal control $\left(\sim 300\right.$ years) would result in a $99 \%$ reduction of ${ }^{90} \mathrm{Sr}$ and ${ }^{137} \mathrm{Cs}$ activities $(\sim 10$ half-lives). Periodic monitoring for fugitive radionuclides in trees, litter fall, vegetation, soil, surface water, and groundwater should be performed.

- A diagram of the radiological surface conditions at the Trench 6/Leak Site 7.4b area. depicting current radiation levels, surface hot spots, and contaminated tree area (such as Fig. 12 in this report), should be maintained, updated, and mide readily available to authorized personnel requiring access into these areas. Consideration should be given to posting such information at a highly visible location on site. Instructions to contact responsible area personnel (e.g., ORNL Health Physics personnel, ORNL ERP) with current telephone numbers should be included.

- Radiation protection measures (e.g., personal radiation monitoring devices) should be considered for personnel not affiliated with Martin Marietta Energy Systems, Inc., who are involved with activities at the Trench 6/Line Leak Site 7.4b area. (Note: Energy Systems personnel are required to wear badge dosimeters.) All activities that disturb and/or disperse radioactivity in these areas should cease if personnel involved with such operations (e.g., well drilling) do not wear some type of radiation protection gear. Personal respirators would minimize the potential for inhalation of radioactively contaminated soil/dust particles.

- Land stabilization procedures (c.g., carthen caps, hydrologic isolation, and limited in situ grouting or vitrification) should be considered at radioactively contaminated soil areas where high concentrations of intermediate-lived waste products have been verified. 
- External radiai: on levels could be reduced at contaminated areas by covering contaminated ground-surface areas with clean, uncontaminatei sw... However, if eventual remedial action requires removal of contaminated soil, the added cover would increase the volume of waste to be disposed of.

Removal, treatment, and disposal of contaminated material

- At the highly contaminated areas, soil, ground cover, and vegetation could be removed, treated (if required), and disposed of in a designated radioactive waste disposal site. Excavation and removal of the contaminated soil must be carried out in full compliance with current guidelines. It is essential that ORNL Health Physics personnel be present to monitor activities associated with any disturbance of soil at the Trench 6/Leak Site $7.4 b$ area.

- Identified contaminated trees could be removed and buried in a designated radioactive waste disposal site; however, extensive tree removal may facilitate ${ }^{90} \mathrm{Sr}$ leaching from the site. ${ }^{5}$ A meeting involving key ORNL personnel from the Environmental Sciences Division and the former Environmental and Health Protection Division was held to discuss strategies for dealing with ${ }^{90} \mathrm{Sr}$-contaminated trees in the area around Trench 7. The meeting attendees concluded that at least for the present, it is preferable to leave the trees in place so as not to create an ecological disturbance that could potentially facilitate radionuclide releases from the site.

- Land stabilization procedures (e.g., earthen caps, hydrologic isolation, localized in situ grouting or vitrification) should be considered for contaminated areas enduring limited remediation or if remedial actions are insufficient in attaining acceptable decontamination levels of the affected areas. 


\section{REFERENCES}

1. B. P. Spalding, Environmental Sciences Division, Oak Ridge Natl. Lab., personal communication to Remedial Action Program staff, Oak Ridge Natl. Lab., March 1987.

2. W. F. Ohnesorge, D. W. Parsons, T. W. Oakes, and J. L. Malone, An Environmental Radiological Survey of the Intermediate-Level Waste System Pipeline, ORNL/TM-7858, Oak Ridge Natl. Lab., September 1981.

3. T. E. Myrick, B. A. Berven, W. D. Cottrell, W. A. Goldsmith, and F. F. Haywood, Procedures Manual for the ORNL Radiological Survey Activities (RASA) Program, ORNL/TM-8600, Martin Marietta Energy Systems, Inc., Oak Ridge Natl. Lab., April 1987.

4. D. S. Landeen and R. M. Mitchell, "Radionuclide Uptake by Trees at a Radwaste Pond in Washington State," Health Phys. 50(6), 769-74 (June 1986).

5. C. T. Garten, Jr., Environmental Sciences Division, Oak Ridge Natl. Lab., personal communication to J. K. Williams, Health and Safety Research Division, Oak Ridge Natl. Lab., July 1991.

6. E. L. Etnier and R. S. Weaver, Applicable or Relevant and Appropriate Requirements (ARARs) for Remedial Action at the Oak Ridge Resenvation, A Compendium of Major Environmental Laws, ES/ER/TM-1, Martin Marietta Energy Systems, Inc., Oak Ridge Natl. Lab., July 1991.

7. D. C. Kocher, "Proposed Guidance for the Development of Remedial Action Strategies at Radioactively Contaminated Sites," Racilation Protection Management 6(3), 44-52 (May/June 1989). 


\section{DISTRIBUTION}

ORNL/ER-37

1. L. V. Asplund/N. W. Durfee

2. C. F. Baes III

3. L. D. Bates

4. B. A. Berven

5. H. M. Braunstein

6-7. T. W. Burwinkle

8. H. M. Butler

9. R. F. Carrier

10-11. K. W. Cook

12. W. D. Cottrell

13. F. K. Edwards, Jr.

14. R. D. Foley

15. M. K. Ford

16. M. W. Francis

17-18. H. R. Gaddis

19. S. B. Garland II

20. C. T. Garten, Jr.

21. C. D. Goins

22-25. L. Holder, Jr.

26. D. D. Huff

27. L. D. Hyde

28. R. L. Jeffers

29. R. G. Jones

30. S. V. Kaye

31. R. H. Ketelle

32. A. J. Kuhaida, Jr.

33. J. R. Lawson

34. P. Y. Lu
35. L. E. McNeese

36. C. E. Nix

37-38. P. T. Owen

39. P. F. Reeverts

40. R. E. Rodriguez

41. P. S. Rohwer

42. T. H. Row

43. G. E. Rymer

44. T. F. Scanlan

45. P. A. Schrandt

46. B. P. Spalding

47-52. R. E. Swaja

53. J. H. Swanks

54. D. W. Swindle

55-58. P. F. Tiner

59-60. J. R. Trabalka

61-64. M. S. Uziel

65. C. K. Valentine, Jr.

66. J. E. Van Cleve, Jr.

67. L. D. Voorhees

68. R. K. White

69-74. J. K. Williams

75-80. MAD Records Center

81. Central Research Library

82. ORNL Technical Library, Y-12

83-84. Laboratory Records-RC

85-89. ER Document Mgt Center-RC

90. ORNL Patent Section

91. Office of Assistant Manager for Energy Research and Development, DOE Field Office, Oak Ridge, P.O. Box 2001, Oak Ridge, TN 37831-8600)

92-93. J. R. Kannard, Program Manager, Bechtel National, Inc., P.O. Box 350, Oak Ridge Corporate Center, 151 Lafayctte Drive, Oak Ridge, TN 37831-0350

94. P. H. Edmonds, Radian Corporation, $120 \mathrm{~S}$. Jefferson Circle, Oak Ridge, TN 37830

95-98. W. E. Murphie, Department of Energy, Office of Environmental Restoration, Eastern Area D\&D Branch, EM-423 (GTN), Washington, DC 20545

99-100. S. S. Perkins, DOE Ficld Office, Oak Ridge, Information Resource Center, 105 Broadway, Oak Ridge, TN 37830

101-102. S. P. Riddle, DOE Ficld Office, Oak Ridge, P.O. Box 2001, Oak Ridge, TN $37831-8541$ 
103-104. R. C. Sleeman, DOE Field Office, Oak Ridge, P.O. Box 2001, Oak Ridge, TN 37831-8541

105-106. Office of Scientific and Technical Information, P.O. Box 62, Oak Ridge, TN 37831 

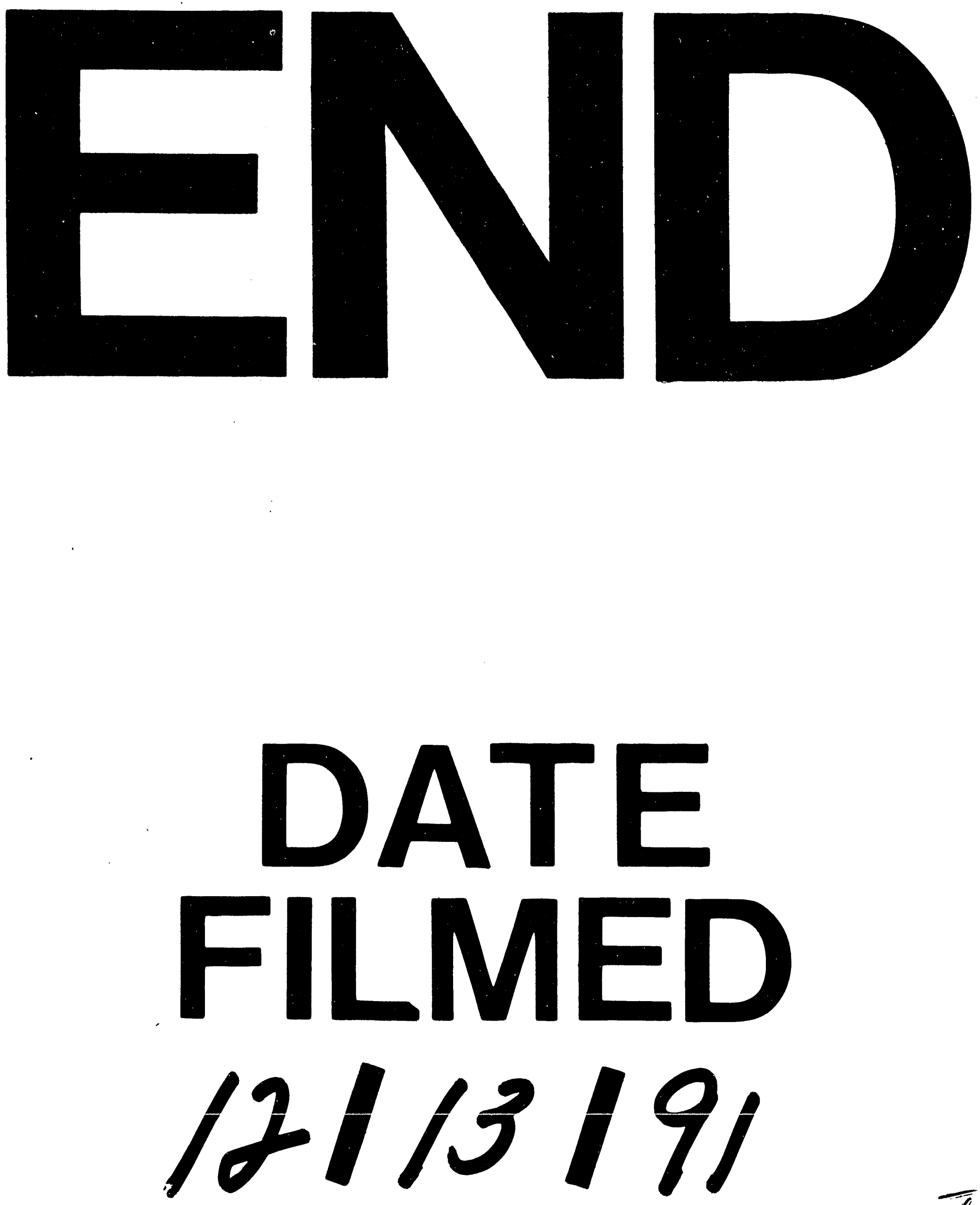
